\title{
UNION BUSTERS AND FRONT-LINE SUPERVISORS: RESTRICTING AND REGULATING THE USE OF SUPERVISORY EMPLOYEES BY MANAGEMENT CONSULTANTS DURING UNION REPRESENTATION ELECTION GAMPAIGNS
}

\section{Charles T. Joyce $\dagger$}

Frontline supervision is the company's first line of defense against union invasion of the workplace.... Management must be certain that it convinces supervisors that they have a personal stake in keeping the union out.

-Alfred DeMaria, Management Consultant*

Supervisors are made to feel that his or her [sic] own personal worth, loyalty to the institution, and future... depend on how many "No" votes he or she can produce. Several hours a day of having this drummed into their heads produces a corps of supervisors primed to make life a nightmare for anyone who supported the Union. Workers are cornered and lectured about the Union's supposed evils. They are pumped-sometimes subtly, sometimes blatantly-for information about their own sympathies and those of their co-workers. The daily pressure, the disruption of routine, the barrage of anti-union propaganda, the personal attacks on Union supporters-I can tell you from my own experience with . . . workers who are seeking to unionize . . . that going to work in the morning soon becomes something to dread....

-Nancy Mills, Union Organizer**

† B.A. 1983, University of Virginia; J.D. Candidate 1987, University of Pennsylvania.

* A. DeMaria, How Management Wins Union Organizing Campaigns 193 (1980).

** Pressures in Today's Workplace: Oversight Hearings Before the Subcomm. on Labor-Management Relations of the House Comm. on Education and Labor, 96th Cong., 1st \& 2d Sess. 102 (1979) (statement of Nancy Mills, Massachusetts Hospital Workers Union, Local 880, Service Employees International Union, AFL-CIO). 


\section{INTRODUCTION}

In recent years, the unrestrained activities of an increasing number of management labor relations consultants ${ }^{1}$ have become a focus of critical concern. ${ }^{2}$ Although most consultants publicly pledge compliance with labor laws, the accumulated evidence strongly suggests that consultants habitually violate both the spirit and the letter of these laws. ${ }^{3}$

1 The Labor-Management Reporting and Disclosure Act (LMRDA) of 1959 (Landrum-Griffin Act) defines a "labor relations consultant" as "any person who, for compensation, advises or represents an employer, employer organization, or labor organization concerning employee organizing, concerted activities, or collective bargaining activities." 29 U.S.C. $\S 402(\mathrm{~m})(1982)$. This Comment focuses on individuals or firms who assist employers in resisting union organizational campaigns.

2 This concern is reflected in legal journals, see, e.g., Bernstein, The Evolution of the Use of Management Consultants in Labor Relations: A Labor Perspective, 36 LAB. L.J. 292 (1985); Bernstein, Union-Busting: From Benign Neglect to Malignant Growth, 14 U.C. DAvis L. REv. 1 (1980) [hereinafter Bernstein, Union-Busting]; Bethel, Profiting from Unfair Labor Practices: A Proposal to Regulate Management Representatives, 79 Nw. U.L. REv. 506 (1984); Labor Relations Consultants: Issues, Trends, and Controversies, 119 Lab. Rel. Rep. (BNA) No. 15 (June 24, 1985) [hereinafter BNA Report] (a BNA special report); Note, The Liability of Labor Relations Consultants for Advising Unfair Labor Practices, 97 HARv. L. REv. 529 (1983); trade organs, see, e.g., AFL-CIO Nat'L ORg. Coordinating Comm., Report on UNION BUSTERS [hereinafter RUB SHEET]; Fulmer, Resisting Unionization: How Outsiders Working for You Can Work Against You, Business Horizons, Jan.-Feb. 1982, at 19-22; Lagerfeld, The Pop Psychologist as Union Buster, AFL-GIO AM. Federationist, Nov. 1981, at 6; the public press, see, e.g., Chernow, The New Pinkertons, Mother Jones, May 1980, at 50; English, Business is Booming for "Union Busters," U.S. News \& WoRLD ReP., May 16, 1983, at 61; Widder, Blocking Unions is a Business, Chicago Tribune, Jan. 11, 1982, $\S 4$ at 10-11, col. 2; Martin, Labor Nemesis: When the Boss Calls in This Expert, the Union May Be in Real Trouble, Wall St. J., Nov. 19, 1979, at 1, col. 6; and among state and federal lawmakers, see, e.g., Oversight Hearings on Landrum-Griffin Act: Hearings Before the Subcomm. on Labor-Management Relations of the House Comm. on Education and Labor, 98th Cong., 2d Sess. (1984) [hereinafter Oversight Hearings] and subsequent report, StafF of SUbCOMM. ON LABOR-MANAGEMENT RELations of THE House Comm. ON Education and Labor, 98Th Cong., 2d Sess., The ForgotTEN LAW - Disclosure of Consultant and EMPloyer ACTIVITY Under THE LMRDA (Comm. Print 1985) [hereinafter LMRDA REPORT]; Pressures in Today's Workplace: Oversight Hearings Before the Subcomm. on Labor-Management Relations of the House Comm. on Education and Labor, 96th Cong., 1st \& 2d Sess. (vols. 1-4) (1979-1980) [hereinafter Pressures Hearings] and subsequent report, STAFF of Subcomm. on Labor-Management Relations of the House Comm. ON Education and Labor, 96Th Cong., 2d Sess., Pressures in Today's Workplace 25-50 (Comm. Print 1980) [hereinafter Pressures Report]; N.Y. State Assembly Standing Comm. on Labor, a Report on the Plight of the Collective BarGAINING SYSTEM, Assembly of 1984, at 6-12, 32-39 (1984) [hereinafter N.Y. LABOR REPORT].

3 The activities of management consultants, especially in regard to union organizing campaigns, "developed into the predominate topic" of the 1979-1980 House Subcommittee Hearings on "Pressures in Today's Workplace." PREssures REPORT, supra note 2 , at 25. The Subcommittee identified one common characteristic of consultant-led anti-union campaigns as "legal tactics that emphasize delay and manipulation of the procedures of the law, sometimes to the extent of advising its violation." Id. at 31, 36- 
The growing presence of consultants on the American industrial landscape $e^{4}$ undoubtedly contributes to and reflects on an increasing stridency in management opposition to unionization. This, in turn, is considered a major determinant in the phenomenal rise in unfair labor practices $^{5}$ and the precipitous decline in union membership. ${ }^{8}$

Although many portray themselves as the "marriage counselor[s]" of employer-employee relations, producing and promoting progressive

38. Similarly, after a series of hearings in 1984, the New York State Assembly Standing Committee on Labor concluded that the activities of management consultants "almost always evade the spirit and often the letter of the U.S. Labor Laws." N.Y. LABOR REPORT, supra note 2, at 39. A recent empirical study of election campaigns demonstrated that, under the National Labor Relations Act (NLRA), both \& 8(a)(1) and § 8(a)(3) violations, 29 U.S.C. $\S 158(a)(1)$, (a)(3) (1982), are more likely to occur when a company is represented by a consultant. See Cooper, Authorization Cards and Union Representation Election Outcome: An Empirical Assessment of the Assumption Underlying the Supreme Court's Gissel Decision, 79 Nw. U.L. REv. 87, 126 \& table 17 (1984). A 1982-1983 AFL-CIO survey found that union activists were more likely to be discharged in a consultant-run campaign. See Oversight Hearings, supra note 2, at 279 (statement of Charles McDonald, Executive Assistant to the Director, Department of Organization and Field Services, AFL-CIO).

4 The labor relations consulting industry has grown dramatically since the early 1970's. The AFL-CIO estimates that there are currently over 1000 firms and 1500 individual practitioners engaged in the "full-time activity of preventing unionization." 1 Pressures Hearings, supra note 2, at 410 (statement of Robert Georgine, President, Building and Construction Trades Dep't, AFL-CIO). According to the chairperson of the board of one of the largest of these firms, the labor relations consulting industry has increased ten-fold over the last decade. See 3 Pressures Hearings, supra note 2, at 112 (statement of Herbert Melnick, Chairperson of the Board, Modern Management, Inc.).

- See R. Freeman \& J. Medoff, What Do Unions Do? 230-33 (1984). Between 1957 and 1980, the number of employer unfair labor practice charges increased by $750 \%$ and the percentage found meritorious almost doubled. See Weiler, Promises to Keep: Securing Workers' Rights to Self-Organization Under the NLRA, 96 HARv. L. REV. 1769, 1780 \& n.34 (1983). In 1980, one out of every 20 workers who voted for a union in an election campaign was fired for union activity. See R. FREEMAN \& J. MEDOFF, supra, at 232.

- See Dickens \& Leonard, Accounting for the Decline in Union Membership, 1950-1980, 38 Indus. \& LAB. REL. REv. 323, 332-33 (1985) (arguing that the decline in the rates of union organizing and National Labor Relations Board (NLRB) election success accounts for much more of the drop in union membership than economic factors attendant on a transforming economy). The premise that managerial opposition significantly accounts for the diminished union success rate in NLRB elections has been challenged. See J. GetMan, S. Goldberg \& J. Herman, Union RepreSENTATION ElEctions: LAW AND ReALITY (1976). Numerous critics of the Getman, Goldberg, and Herman study, however, point to both methodological and interpretive flaws in its analysis. See Dickens, The Effect of Company Campaigns on Certification Elections: Law and Reality Once Again, 36 INDUS. \& LAB. REL. REv. 560 (1983); Eames, An Analysis of the Union Voting Study from a Trade-Unionist's Point of View, 28 STAN. L. REV. 1181 (1976); Flanagan, The Behavioral Foundations of Union Election Regulation, 28 STAN. L. REv. 1195 (1976); Martin, Employee Characteristics and Representation Election Outcomes, 38 INDUs. \& LAB. REL. REV. 365, 375 (1985). After a review of all the available literature, Freeman and Medoff conclude that managerial opposition accounts for "a quarter to a half" of the decline in union electoral success. R. FreEMAN \& J. Medoff, supra note 5, at 237; see also infra note 8. 
management policies that render unionism unattractive and unnecessary for their client's workforce, ${ }^{7}$ consultants most often are not solicited until a union has begun its attempt to organize the workers. A 1980 report of the House Subcommittee on Labor-Management Relations concluded:

With few exceptions, the consultant does not arrive on the scene until union activity has begun. They are called in to put out the fire with no time or place for long-term planning of a stable, productive and satisfied workforce. They cannot focus on broad management policy nor on the lasting implications of issues raised during an organizational campaign. .. They are hired to win an election. ${ }^{8}$

7 See 3 Pressures Hearings, supra note 2, at 83 (Melnick's statement); L. JACKSON \& R. Lewis, Winning NLRB Elections: MANAgement's STRATEgy and Preventive Programs 3-11 (1972); Sheridan, Management Consultants, in New York University Conference on Labor 121, 132 (1980), reprinted in Oversight Hearings, supra note 2, at 717, 728 ("Consultants who have advised employers to 'do the right thing by their employees' have automatically removed some of the causal factors which create the fertile loam from which union organizational campaigns spring.").

B PREssures RePORT, supra note 2, at 25-26. But see BNA Report, supra note 2, at 38 (John Sheridan, of the consulting firm John Sheridan Associates, estimates that $80 \%$ of his firm's business consists of preventive work rather than counter-organizing). A 1982-1983 AFL-CIO survey estimates that consultants are used in $85 \%$ of all union election campaigns. See BNA Report, supra note 2, at 7 . The actual impact of management consultants on union representation election outcomes is the subject of some debate. One prominent consulting firm, for example, claimed approximately a 93\% success rate in elections in which it was involved between 1977 and 1979. See Letter from Joseph F. Vella, Principal, Modern Management, Inc., to House Subcomm. on LaborManagement Relations (Apr. 7, 1980), reprinted in 3 Pressures Hearings, supra note 2 , at 125-26. Such figures, however, have been disputed in labor circles. See BNA Report, supra note 2, at 9. Scholarly research has not yet resolved the question of consultant effectiveness. See Lawler, The Influence of Management Consultants on the Outcome of Union Certification Elections, 38 Indus. \& LAB. ReL. Rev. 38, 46-47 (1984) (study of consultant involvement in 130 elections in retail grocery outlets, finding such activity quite effective in securing management victory in closely contested races). But Cooper, supra note 3, at 126, reported that the "use of consultants had no demonstrable impact in improving the employer's likelihood of success in the election." Both studies, however, concede methodological limitations that underestimate the true effect of consultants in organizational campaigns. Cooper draws her data solely from NLRB files. See id. at 123. Because evidence of consultant involvement is unearthed by the NLRB only by chance, see 4 Pressures Hearings, supra note 2, at 20 (statement of William Lubbers, General Counsel, NLRB), Cooper admits that her data "can be expected to provide a somewhat inexact measure" of effectiveness. Cooper, supra note 3, at 123. Similarly, Lawler notes that because he derives his samples from reports filed by consultants pursuant to the Landrum-Griffin Act requirements, with which consultants chronically fail to comply, see infra text accompanying notes $217-25$, his estimate "may understate the true influence of consultants on election outcomes." Lawler, supra, at 46.

In light of the equivocality of these studies, perhaps the most impressive measure of consultants' efficacy in union campaigns is the fact that management annually spends an estimated $\$ 100$ to $\$ 500$ million to secure the full range of consultants' ser- 
With their time thus limited, management consultants summoned to quell a union drive typically provide far more than legal advice to the employer; they develop and direct the entire counter-organizational effort, frequently operating from on-site offices and commanding considerable authority over the use of the employer's supervisory personnel. ${ }^{2}$

This authority is crucial to the success of a consultant-led campaign. ${ }^{10}$ Generally, because front-line supervisors are the only management representatives who maintain regular contact with the employees and, therefore, typically enjoy a better rapport with workers than do members of top management, ${ }^{11}$ they serve as an excellent conduit by which to disseminate propaganda concerning the union attempting to organize. ${ }^{12}$ Furthermore, their close daily contact makes the supervisors' observations about workers' attitudes "the best barometer of employee feeling." 13 Thus, supervisors are invaluable in determining the extent of pro-union sentiment in the shop ${ }^{14}$ and in identifying both the union activists, who frequently then are isolated from the rest of the workforce and subjected to harassment and discriminatory treatment, ${ }^{15}$ and the undecided, who become the critical focus of the consultant's

vices. See BNA Report, supra note 2, at 6 . For reasons addressed below, see infra text accompanying notes 216-19, it is difficult to find hard figures on specific campaign expenditures. Available examples, however, are telling. An unsuccessful consultant-conducted campaign cost Boston University $\$ 275,000$ in 1979. See Berger, Disunion at the -Phoenix, The Real Paper (Boston), November 3, 1979, reprinted in 3 Pressures Hearings, supra note 2, at 200, 201. A victory in the representation election at St. Elizabeth's Hospital in Boston cost management an estimated $\$ 1,500,000$ in consulting fees. See 1 Pressures Hearings, supra note 2, at 109 (statement of Nancy Mills, Massachusetts Hospital Workers Union, Local 880, Service Employees International Union, AFL-CIO). One consultant estimates that employers spend $\$ 500$ per person per bargaining unit on consultant work in election campaigns. See BNA Report, supra note 2, at 6.

- See 1 Pressures Hearings, supra note 2, at 424 (Georgine's statement); Bethel, supra note 2, at 520-22; Oversight Hearings, supra note 2, at 280 (McDonald's statement). For examples of on-site control by consultants, see St. Francis Hospital, 263 N.L.R.B. 834, 847-48 (1982) and cases cited in Bethel, supra note 2, at 522 n.70. But cf. BNA Report, supra note 2, at 15 (quoting several consultants who deny that they exercise such control).

${ }^{10}$ See 1 Pressures Hearings, supra note 2, at 28 (statement of Alan Kistler, Director of Organization and Field Services, AFL-CIO); id. at 416 (Georgine's statement); 3 Pressures Hearings, supra note 2, at 76 (Melnick's statement); N.Y. LABOR RePort, supra note 2, at 33; PRESSURes RePORT, stupra note 2, at 32.

12 See A. DeMaria, How Management Wins Union Organizing CamPAIGNS 192 (1980).

12 See N.Y. LABOR REPORT, supra note 2, at 33.

33.

ia A. DeMaria, supra note 11, at 102; see Pressures RePort, supra note 2, at

14 See A. DeMaria, supra note 11, at 208-10.

1s See infra text accompanying notes 6-67. 
campaign of persuasion. ${ }^{16}$

Consultants, moreover, have a vested interest in using supervisors to carry out their anti-union efforts. Operating solely through front-line managers, consultants scrupulously avoid "direct contact" with employees and thus, according to current legal interpretation, may be exempted from publicly disclosing their activities under the reporting requirements of the Labor-Management Reporting and Disclosure (Landrum-Griffin) Act of 1959 (LMRDA). ${ }^{17}$ Additionally, by employing supervisors as a shield, the consultant's presence during the campaign often remains undetected, thereby preventing organizers from focusing attention on the high-priced "outsider" hired to counter the union drive. ${ }^{18}$ Accordingly, consultants contend: "Management cannot afford to allow supervisors to engage in 'business as usual' during [a] campaign."10 Rather, supervisors must zealously carry the anti-union message to the employees. Consultants do not assume, however, that the enthusiastic participation of first-level supervisors in an anti-union campaign will be automatically forthcoming. Front-line managers may develop an affinity toward their workers, bred from daily contact and the practical necessity of nurturing a harmonious working relationship to maintain production levels. "Scratch the skin of a supervisor," complains one consultant, "and you'll find a rank-and-file employee."20

Management consultants, therefore, employ a variety of tactics at the outset of a counter-organizing campaign to ensure the active cooperation of the supervisory staff. These methods range from subtle hints of promotion or added benefits, to dire predictions of the diminished authority a supervisor will command if the union prevails, to outright threats of demotion or discharge. ${ }^{21}$ The line supervisor is repeatedly

16 A. DeMAria, supra note 11, at 201 notes:

Supervisors can also play a key role by reporting to management on what they perceive to be the number and identity of uncommitted voters in their departments. In most elections, the "independent" vote determines the result, and it is extremely important for management to have some perspective on the size of this vote and the people who compose the group.

See also 1 Pressures Hearings, supra note 2, at 29 (Kistler's statement) ("[S]upervisors will go heavily after the undecided . . .."); 21 RUB SHEET, supra note 2, at 1 (Oct. 1980) (consultants instructing supervisors to concentrate on uncommitted workers).

1729 U.S.C. $\S \S 401-531$ (1982); see infra text accompanying notes 220-25.

18 See infra text accompanying notes 187-95.

10 A. DeMaria, supra note 11, at 192; see also West CoAst Indus. RelaTIONS Ass'N, Inc., The Non-Union Company (1976) (material from a July 1976 management consultant seminar), reprinted in 1 Pressures Hearings, supra note 2, at 196-97.

201 Pressures Hearing, supra note 2, at 28 (Kistler's statement).

21 See 3 Pressures Hearings, supra note 2, at 212-13, 215 (statement of John Jones, Lexington, N.C.). 
informed that because she is not protected by the National Labor Relations Act (NLRA) ${ }^{22}$ she is compelled to obey the consultant during the anti-union drive. ${ }^{23}$

Unfettered consultant control over supervisory employees, however, is antithetical to the principles and values expressed in the federal labor statutes. Conditioning a supervisor's job security on her counterorganizing efforts often serves to undermine the workers' statutory right to select collective bargaining representatives free from fear or harassment. It also inevitably works to destroy the harmonious and efficient operation of the workplace. ${ }^{24}$ Furthermore, the consultants' use of front-line management as a shield ${ }^{26}$ frustrates employee free choice ${ }^{26}$ and is contrary to the legislative intent underlying the reporting and disclosure requirements of the Landrum-Griffin Act. ${ }^{27}$

This Comment proposes that consultants' use of front-line supervi-

22 Pub. L. No. 74-198, ch. 372, 49 Stat. 449 (1935) (codified as amended at 29 U.S.C. $\$ \S 151-169$ (1982)). Supervisors were excluded from the protection of the NLRA by the 1947 Taft-Hartley Amendments, Labor-Management Relations Act of 1947, Pub. L. No. $80-101$, ch. 120, 61 Stat. 136 (codified as amended at 29 U.S.C. $\S \S 141-197$ (1982)).

2s See 1 Pressures Hearings, supra note 2, at 416 (Georgine's statement); PResSURES REPORT, supra note 2 , at 32.

24 The first section of the NLRA declares that the policy of the United States is to protect "the exercise by workers of full freedom of association, self-organization, and designation of representatives of their own choosing, for the purpose of negotiating the terms and conditions of their employment or other mutual aid or protection." 29 U.S.C. $\S 151$ (1982). Upholding the constitutionality of the Act in NLRB v. Jones \& Laughlin Steel Corp., 301 U.S. 1 (1937), the Supreme Court stated that the "statute goes no further than to safeguard the right of employees to self-organization and to select representatives of their own choosing . . . without restraint or coercion by their employer." Id. at 33. Declaring this to be a "fundamental right," the Court went on to hold: "Discrimination and coercion to prevent the free exercise of the right of employees to self-organization and representation is a proper subject for condemnation by competent legislative authority." Id.; see also Klare, Judicial Deradicalization of the Wagner Act and the Origins of Modern Legal Consciousness, 1937-1941, 62 MrNN. L. REv. 265, 281-312 (1978) (providing an excellent discussion of the "goals and perceptions" of the NLRA and an account of how they were muted by subsequent judicial reaction).

The preamble of the NLRA also indicates an intent to maintain "industrial peace." Although this rationale normally is used to justify the regulation of broad scale "economic weapons," it remains relevant at the level of the individual shop. Indeed, as Klare notes, the NLRA, in aiming to remove "certain recognized sources of industrial strife and unrest, [and] encourag[e] practices fundamental to the friendly adjustment of disputes," 29 U.S.C. $\$ 151$ (1982), operates on the "assumption that employers would eventually come to their senses and accept collective bargaining as more productive from the long-run standpoint of the business system than intransigent efforts to hold back the clock." Klare, supra, at 281 n.53. The excessive antagonisms engendered by consultant-controlled supervisory anti-union campaigns, see infra text accompanying notes 54-82, clearly are contrary to this legislative goal.

2s See supra text accompanying notes 17-18.

${ }^{26}$ See infra text accompanying notes 189-97.

27 See infra text accompanying notes 198-215 \& 225-26. 
sors during union representation election campaigns be restricted and regulated. Part I describes a consultant-led, supervisor-run management campaign and demonstrates its deleterious effects on employees' organizational rights and on the productivity of the workplace. Part II contends that supervisors who refuse to participate in a management counter-organizing campaign should be protected from fear of reprisal. This contention is based on a reexamination of the history of the TaftHartley supervisory exclusion amendments and a principled resolution of inconsistent and unworkable National Labor Relations Board (NLRB) precedent. Finally, Part III argues that even when supervisors willingly participate in a campaign, consultants should not be permitted to operate through them to escape the LMRDA disclosure requirements. Indeed, because the law is specifically fashioned to command public awareness of their conduct, consultants should be compelled to report their activities.

\section{Frightened Supervisors, Frightened Employees: ${ }^{28}$ The anatomy of a Consultant-Led Management Campaign}

Management consultants claim that they develop strategies uniquely "tailored to suit the client's particular needs." virtually all consultant-led campaigns employ front-line or primary supervisors as "the critical link in the communications network" between management anxious to avoid unionization and employees who may be considering it. ${ }^{30}$ By extrapolating from consultant literature, testimony before legislative hearings of organizers and employees who have faced a consultant's anti-union effort, and NLRB reports, it is possible to develop a composite picture of a typical counter-organizational campaign and to identify its adverse effects on supervisors, employees, and the functioning of the workplace.

The consultant's first move in confronting an organizing drive is to meet with first-level managers and outline their pre-election role. Consultants' promotional literature benignly describes these training sessions as meetings during which the supervisor is taught how to "improve [her] skills in communicating with and responding to

28 See 1 Pressures Hearings, supra note 2, at 110 (Mills' statement) (Consultants "make it a point to frighten the supervisors, and if they frighten the supervisors, then it is up to the supervisors to turn around and frighten the employees.").

20 Letter from Joseph F. Vella, Principal, Modern Management, Inc., to House Subcomm. on Labor-Management Relations (Apr. 7, 1980), reprinted in 3 Pressures Hearings, supra note 2, at 127.

${ }^{30} 3$ Pressures Hearings, supra note 2, at 76 (Melnick's statement). 
employees."31 Line managers who undergo such sessions, however, tend to view them in a different light. One supervisor, testifying anonymously before a state investigative committee, described these initial encounters with the consultant as "intimidating," while her fellow managers likened them to "brainwashing" sessions. ${ }^{32}$

During these meetings, consultants familiarize supervisors "with the spirit of the company's opposition" to the union drive ${ }^{33}$ and assign each supervisor a group of employees whose sympathies she is instructed to ascertain..$^{34}$ Once supervisors determine in which direction the employees are inclined, some consultants simply urge the line managers to speak to the union adherents and "turn them around in their thinking."35 Most consultants, however, require a more rigid approach. Armed with anti-union literature and speeches prepared by the consultant behind the scenes, supervisors are commanded to engage employees in a series of one-on-one discussions. ${ }^{36}$ The supervisors must report to the consultant, at regular intervals, their progress in these encounters. As the election draws near, these feedback sessions between supervisor and consultant become a daily, and even thrice-daily, routine. ${ }^{37}$

s1 Backgrounder on Modern Management, Inc. (company description prepared for Modern Management by John Schmadeke), reprinted in 3 Pressures Hearings, supra note 2 , at $122,123$.

32 N.Y. LABOR REPORT, supra note 2, at 34.

ss A. DeMARIA, supra note. 11 , at 96 .

st For example, General Telephone and Electric's counter-union campaign conducted by the consultant firm of John Sheridan Associates commenced with supervisors receiving instruction to determine the extent of pro-union sentiment by means of a rating system:

Every supervisor was instructed to enter a plus mark following the name of every employee opposed to organizing; a plus mark with a circle around it if the employee was strong against the union; a minus mark if the employee leaned toward the union; or a minus mark with a circle around it if the employee was an active union supporter. A question mark indicated that the supervisor was unaware of the employee's true feelings .... Mr. Sheridan explained that question marks would not be tolerated over an extended period of time....

1 Pressures Hearings, supra note 2, at 611 (statement of Charles Pillard, International President, IBEW); see also GTE Lenkurt, Inc., 204 N.L.R.B. 921 (1973) (GTE violated $\S 8(\mathrm{a})(1)$ by using supervisors to determine workers' union sympathies).

ss 3 Pressures Hearings, supra note 2, at 212 (Jones' statement).

38 See 1 Pressures Hearings, supra note 2, at 29 (Kistler's statement).

s7 See St. Francis Hospital, 263 N.L.R.B. 834, 847 (1982); 3 Pressures Hearings, supra note 2, at 175 (statement of Robert Muehlenkamp, Director of Organization, National Union of Hospital and Health Care Employees, Local 1199). As noted supra text accompanying notes 14-16, the information gleaned from the front-line manager enables the consultant to gauge the efficacy of the counter-organizing campaign and, in many cases, to learn the identities of those sympathetic to and opposed to unionization. See GTE Lenkurt, 204 N.L.R.B. at 926-27; St. Francis Hospital, 263 N.L.R.B. at 848; RUB SheET, Aug. 1980, at 19 (special ed.).

The latter may be encouraged subtly to speak on the company's behalf to their 
Methods by which management consultants command the active participation of front-line supervisors vary. Supervisors sometimes can be seduced by the hint of promotion and can be made to believe "that rewards [will] be theirs for being part of the program."38 Conversely, consultants may indicate to supervisors that successful resistance to the union drive depends upon the supervisors, and that failure "would be the supervisors [sic] fault and . . . would be remembered."s9 Consultants may also stress that in a unionized shop supervisors might have less authority in dealings with employees. ${ }^{40}$ "These factors," suggests one consultant, "once brought to the attention of the supervisors, will often result in a motivated front-line force ready to do battle with the union." 11

Some line managers, for both personal and practical reasons, remain unwilling to become the vehicle by which the consultant organizes the anti-union campaign. ${ }^{42}$ Neutrality in front-line supervision during a representation election campaign, however, cannot be tolerated. ${ }^{43}$ Consultants quickly remind supervisors that, because supervisors generally are excluded from statutory protection by virtue of the Taft-Hartley Amendments to sections 2(3), 2(11), and 14(a) ${ }^{44}$ of the NLRA, , $^{4}$ "[e]mployers are entitled to the undivided loyalty of their supervisors and have the full right under the law to discharge [a] supervisor [ ] . . for failure to follow lawful instructions" relating to an anti-union cam-

coworkers. DeMaria advises:

[Loyal] [e]mployees cannot be told to campaign affirmatively for the employer or to encourage co-employees to reject the union. Such conduct is an unfair labor practice. But they may be told that they have a right to express their opinion on the union's organizational campaign and that the company therefore is telling them what can be said and the best way to say it.

A. DeMARIA, supra note 11 , at 100 .

The former may be isolated and closely scrutinized so that the employer can develop a pretext for reprisal or discharge. See 1 Pressures Hearings, supra note 2, at 30 (Kistler's statement); id. at 610 (Pillard's statement); id. at 113-14 (statement of Anna Cucchi, former dietary employee, St. Elizabeth's Hospital); 3 Pressures Hearings, supra note 2, at 163 (Muehlenkamp's statement); PRESSURES REPORT, supra note 2, at 34 .

38 3 Pressures Hearings, supra note 2, at 215 (Jones' statement).

so 1 Pressures Hearings, supra note 2, at 417 (Georgine's statement).

${ }^{10}$ See id. at 413; 3 Pressures Hearings, supra note 2, at 215 (Jones' statement).

11 A. DeMaria, supra note 11 , at 198.

42 See 1 Pressures Hearings, supra note 2, at 425 (Georgine's statement); 3 Pressures Hearings, supra note 2 , at 212-13 (Jones' statement).

43 See A. DeMaria, supra note 11, at 192.

14 Pub. L. No. 80-101, ch. 120, 61 Stat. 136 (codified as amended at 29 U.S.C. $\S \S 141-197$ (1982).

${ }^{40}$ Pub. L. No. $74-198$, ch. 372,49 Stat. 449 (codified as amended at 29 U.S.C. $\S \S 151-169$ (1982). 
paign. ${ }^{46}$ One line foreman discovered that his level of loyalty was considered inadequate to meet this standard:

I didn't mention the union [to the employees] pro or con. I was concerned with production. I didn't harass the people and I told Mr. Dickerson that at the meeting . . . .

. . . . Mr. Dickerson stated to me: "John, you are going to either follow the game plan or get off the team." I remarked that "a man's job is not a game and I do not feel that I can do what you require of me." He said: "John, leave your I.D., you are terminated."

Inducements, veiled warnings, and outright threats, ${ }^{48}$ coupled with increasingly frequent feedback meetings, create tremendous pressure for the front-line supervisor as the counter-organizing effort advances. By the final week of one management campaign, a union organizer reported that the line managers "were all nervous wrecks, some of them to the point of irrationality. . . . There was a good bit of cornering and yelling in the halls, personal accusations and even some crying . . . . There was a definite climate of confusion, intimidation, and fear."199

48 A. DeMARIA, supra note 11, at 196; see, e.g., N.Y. LABOR REPORT, supra note 2, at 33; Hament, Are Instructions to Supervisors to Commit Unfair Labor Practices Unlawful Per Se?, 26 LAB. L.J. 281 (1975).

473 Pressures Hearings, supra note 2, at 212-13 (Jones' statement).

is Threats to supervisors grounded in their putative lack of legal protection were repeatedly cited in the 1979-1980 hearings before the House Subcommittee on LaborManagement Relations, see 1 Pressures Hearings, supra note 2, at 28 (Kistler's statement), 416, 425 (Georgine's statement), 610 (Pillard's statement), 649 (statement of the Federation of Nurses and Health Professionals, submitted by Eileen McManus), 652 (statement of The National Union of Hospital and Health Care Employees); 3 Pressures Hearings, supra note 2, at 175 (Muehlenkamp's statement), and such threats were prominently mentioned in the subcommittee's report. See PRESSURES REPORT, supra note 2 , at 32 . Further testimony before the subcommittee demonstrated that such threats were not idle. In one anti-union campaign, consultant Sheridan secured the discharge of an industrial relations manager and a supervisor for not exhibiting "sufficient zeal." 1 Pressures Hearings, supra note 2, at 611 (Pillard's statement); see also 3 Pressures Hearings, supra note 2, at 14 (statement of Carol Miller, nurse, St. Anthony's Hospital) (reporting the replacement by anti-union activist of a supervisor who was ineffective in stopping organizational effort).

101 Pressures Hearings, supra note 2, at 649 (McManus' statement); see also 1 Pressures Hearings, supra note 2, at 29 (Kistler's statement) (Our supervisor came back from these meetings [with the consultant] very tense, sometimes very irritable and on a few occasions, as the election got closer and closer and the meetings were more and more, she got very upset."); id. at 417 (Georgine's statement) ("They came down on [the supervisor] so heavy that ... she was cussing at the top of her lungs-and screaming and broke down into tears, crying. That's what it was like."); 3 Pressures Hearings, supra note 2, at 10,11 (statement of Judy Hammil, President, Denver Fed'n of Nurses and Health Professionals; nurse, Rose Memorial Hospital) ("The effects of the stress produced by the [consultants'] tactics of utilizing supervisory personnel as the primary force in their campaign are highly visible .... The director of 
Some supervisors, faced with such stress, respond by taking forced vacations or by resigning. ${ }^{50}$ Others bravely rebel against the consultant's tactics. ${ }^{51}$ In most cases, however, the employees bear the brunt of their supervisors' frustrations and fears. ${ }^{52}$ As one organizer noted, once consultants "make it a point to frighten the supervisors," the supervisors "turn around and frighten the employees."

Primed by the consultant's demands, supervisors proceed to "make life a nightmare" for workers considering unionization. ${ }^{54}$ Constantly reminded that "no other work is as important . . . as the pressure they put on employees about the Union," ss supervisors "spend virtually their entire time interrogating employees and threatening them about their Union activities and Union support." ${ }^{\text {Be }}$ Evidence of this phenomenon is particularly noticeable in the health care field. At one hospital, for example, supervisors interrupted health care workers attempting to fill out patient reports and trying to comfort a bereaved family, insisting that they discuss the possibility of unionization. ${ }^{57}$ At other hospitals, supervisors interrupted nurses bathing patients, performing tests, handling premature babies in isolettes, and even responding to emergency "stat" calls to force them to accept anti-union literature. ${ }^{.8}$ As the campaign proceeds, this pattern of harassment frequently escalates into section $8(a)(1)$ violations ${ }^{38}$ of employees' section 7 organizational rights. ${ }^{60}$ A recent NLRB case report, characterizing the tenor of one such consultant-led campaign, concluded: "The supervisor[s] did more than state the hospital's position. 'They used every trick that a profes-

nursing has shown a noticeable weight loss and other signs of fatigue.").

${ }^{50}$ See 1 Pressures Hearings, supra note 2, at 417 (Georgine's statement); 3 Pressures Hearings, supra note 2, at 169 (Muehlenkamp's statement).

-1 See 3 Pressures Hearings, supra note 2, at 177 (Muehlenkamp's statement); Berger, supra note 8.

${ }^{82}$ See 1 Pressures Hearings, supra note 2, at 102 (Mills' statement).

${ }^{5 s} I d$. at 110 .

of Id. at 102.

os 1 Pressures Hearings, supra note 2, at 652 (statement of The National Union of Hospital and Health Care Employees).

80 Id.

${ }^{57}$ See 3 Pressures Hearings, supra note 2, at 165 (Muehlenkamp's statement).

${ }^{68}$ See id. at 166 (Muehlenkamp's statement); id. at 9 (prepared testimony of Angela Lasley, nurse, St. Luke's Hospital, Denver, Colo.).

o9 Section 8(a)(1) of the Labor-Management Relations Act (LMRA) provides: "It shall be an unfair labor practice for an employer . . . to interfere with, restrain, or coerce employees in the exercise of the rights guaranteed in section $157 \ldots$. ."29 U.S.C. $\S 158(a)(1)(1982)$.

6o Section 7 of the LMRA provides in relevant part: "Employees shall have the right to self-organization, to form, join, or assist labor organizations, to bargain collectively through representatives of their own choosing, and to engage in other concerted activities for the purpose of collective bargaining or other mutual aid or protection . . . " 29 U.S.G. $\$ 157$ (1982). 
sional interrogator use[s] against a prisoner of war. They created stress, pulled rank, cajoled, threatened, promised, personalized the issue and otherwise attempted to brain-wash the nurses." "B1

Additionally, supervisors often engage in discriminatory treatment, violating section $8(a)(3)$ of the NLRA. ${ }^{62}$ Congressional hearings indicate that this discrimination ranges from transferring and physically isolating union supporters from other workers "in order to minimize their ability to present the union's position," nary warnings, ${ }^{64}$ to outright discharge of employees. ${ }^{68}$ Not only does this action have an obvious impact on employees' organizational rights, it conflicts squarely with the NLRA's stated desire to avoid "industrial strife and unrest" to the extent possible in a regime that ostensibly promotes collective bargaining. ${ }^{68}$ Although a certain measure of friction in the workplace attends any organizational effort, the philosophy of a consultant-led, supervisory-run campaign, which "exalts the short-run over the long-run, presuming that workers will vote against a union if management exercises the correct combination of manipulation, persuasion, and control,"67 clearly exacerbates the adversarial posture of labor-management relations.

This invasion of employees' protected organizational rights is a direct result of consultant control over supervisory conduct. Some consultants actually encourage line supervision to engage in illegal activities. ${ }^{68}$ Others merely refrain from informing supervisors as to what is and what is not permissible persuasion under the $\operatorname{law}^{69}$ and then ignore

61 St. Francis Hospital, 263 N.L.R.B. 834, 844 (1982).

62 Section 8(a)(3) of the LMRA provides in relevant part: "It shall be an unfair labor practice for an employer ... by discrimination in regard to hire or tenure of employment or any term or condition of employment to encourage or discourage membership in any labor organization . . ." 29 U.S.C. § 158(a)(3) (1982).

os Pressures Report, supra note 2, at 34.

of See 1 Pressures Hearings, supra note 2, at 114 (Cucchi's statement); 3 Pressures Hearings, supra note 2 , at 214 (Jones' statement).

os Union activists are discharged $25 \%$ more frequently in consultant-led campaigns than in campaigns in which consultants are not utilized. See Oversight Hearings, supra note 2, at 279 (McDonald's statement). In the manufacturing industry, the likelihood of discriminatory discharge of union supporters is $100 \%$ greater. See id; supra note 3.

66 See supra note 24.

67 PREssuRes REPORT, supra note 2, at 25.

6s See GTE Lenkurt, 204 N.L.R.B. 921, 926-27 (1973) (Supervisors, at consultant's request, reported names of union adherents, thus violating $\S 8(\mathrm{a})(1)$ of the NLRA.).

00 See 2 Pressures Hearings, supra note 2, at 10 (affidavit of John Jones) ("It was only after the election that [the consultant] told us what the 'do's' and 'don't's were as far as the labor law is concerned."). 
violations when they occur. ${ }^{70}$ Furthermore,

[e]ven when supervisors are schooled to operate just inside the law, or to commit only minor violations involving little in the way of effective remedial redress, they will be pressured for results to such a degree that they begin to break the law in more serious forms with threats, intimidation, promises, surveillance, and discipline as the election draws near and as they try to satisfy the [consultant's] demand for results. ${ }^{71}$

One consultant implies that such excesses are acceptable; if supervisors are to be encouraged to "bring management's viewpoint to the employees" they should not be "expected to run a mistake-free campaign."

In addition to violating employee rights, consultants' efforts to win the election decrease efficiency and impair production. For example, it is accepted counter-union strategy to intentionally create "fear and pressure" in the workplace during a representation election drive. ${ }^{73}$ In congressional hearings on workplace pressures held in 1980, a union official noted that "a vicious anti-union campaign ... . disrupts the normal functioning of the workplace. The disruption is then often associated with the union coming onto the scene."'t4 Another union organizer explained:

[T]his transformation of the [workplace] into an armed camp almost always works against the [u]nion, rather than against those who are responsible for it. For one thing, the . . . consultants are invisible; they come into contact only with the

70 See St. Francis Hospital, 263 N.L.R.B. 834, 848 (1982):

The supervisors were asked by Respondent [consulting firm] representatives to report back to them concerning the employees' reactions to the individual written matter. When making these reports . . . the supervisors would, on occasion, give the names of employees along with their reactions to the literature. There is no evidence that any of the supervisors were told to stop that practice. . . . The preponderance of the evidence establishes condonation of the illegal practice by Respondents.

711 Pressures Hearings, supra note 2, at 29 (Kistler's statement).

72 A. DeMaria, supra note 11, at 206.

781 Pressures Hearings, supra note 2, at 102 (Mills' statement); see also PresSURES REPORT, supra note 2, at 35 ("Another technique is the creation of great upheaval in the workplace, transforming the work environment to one of great anxiety and pressure which workers associate with the new presence of a union."). Organizers surveyed in 1983 by the AFL-CIO rated the likelihood of a high degree of "intensity and effectiveness" in consultant-led campaigns as considerably greater than in employer-led efforts. See Oversight Hearings, supra note 2, at 279, 280 (McDonald's statement).

74 1 Pressures Hearings, supra note 2, at 417 (Georgine's statement). 
supervisors. The average worker is unaware of their existence. For another, it is very easy to associate the transformation of one's workplace into a nightmare with the existence of the union drive. After all, it was never like this before all this [u]nion talk started. With any luck, things will go back to normal after the [u]nion's gone. And if the union somehow does win, this hell might become permanent. ${ }^{75}$

Another tactic requires constantly pulling line managers from their work stations for lengthy status meetings. This also impedes the smooth functioning of an enterprise. ${ }^{78}$ Head nurses, for example, compelled to spend increasingly long hours in feedback sessions absent from their units, are unable to coordinate patient care; ${ }^{77}$ staff nurses are assigned particular duties not on the basis of expertise but rather in a way such as to best facilitate the consultant's strategies. ${ }^{78}$ Supervisors typically demand that staffers attend anti-union meetings instead of practical training sessions. ${ }^{79}$ In sum, "patient care takes a backseat" to the anti-union drive. ${ }^{80}$ While the adverse effects of a consultant-supervisor campaign are again most dramatically illustrated in the hospital setting, they are not unique to the health care industry. The House Subcommittee on Labor-Management Relations observed: "While [consultants'] strategies are motivated by the immediate concern of defeating the union, the result can be lingering conflict and antagonism, which is unproductive and debilitating for worker and management alike."81 "We could find no consultant," concluded the subcommittee, "who could point to studies of worker satisfaction or productivity as a measure of their success."

${ }^{28}$ Id. at 102-03 (Mills' statement).

${ }^{76}$ See 3 Pressures Hearings, supra note 2, at 9 (Lasley's statement); id. at 160 61 (Muehlenkamp's statement); St. Francis Hospital, 263 N.L.R.B. 834, 842 (1982).

77 See 3 Pressures Hearings, supra note 2, at 11 (Hammil's statement); id. at 161 (Muehlenkamp's statement).

78 See id. at 16 (Miller's statement).

79 See id. at 164 (Muehlenkamp's statement). In one instance, an entire shift of hospital orderlies was requested to meet with the union for over an hour; doctors and nurses were forced to transport patients while bloodwork "sat on the floor" instead of being taken to the lab. See 1 Pressures Hearings, supra note 2, at 110 (Mills' statement).

so 1 Pressures Hearings, supra note 2, at 110 (Mills' statement).

11 PRessures Report, supra note 2, at 26.

82 Id. 


\section{The Limits of Supervisory Loyalty: Creating Section 8(a)(1) Protection for tHe Reluctant Supervisor IN A Union RePresentation Election Gampaign}

Management's "right" to the "undivided loyalty" of its supervisors, and concomitant use of consultants in election campaigns, results in the manipulation of line managers, ${ }^{83}$ the violation of employee-protected rights, ${ }^{84}$ and a loss of efficiency and productivity.$^{85}$ The number of industrial ills produced by such loyalty indicates the need to reexamine this doctrine, its basis in industrial and legislative history, and its contemporary parameters as reflected in the case law. Indeed, a frank reappraisal demonstrates its irrelevance to the reluctant supervisor in a counter-organizing campaign and suggests the need for a new approach.

\section{A. The Industrial Origins of the Supervisory Loyalty Doctrine}

The current contours of the supervisory loyalty doctrine in a representation election setting are considered quite broad by most commentators. It is "fundamental as to be beyond citation that supervisory employees are not protected under the [Taft-Hartley] Act when they engage in concerted activity." ha[ve] no legally guaranteed freedom of choice on the subject of unionization,"87 employers are entitled to their supervisors' "undivided loyalty."88 Furthermore, because supervisors are "vital to combating attempts at union organization,"88 their refusal to join in any anti-union activity that falls short of a demonstrable unfair labor practice is considered disloyalty, and it is a legitimate ground for reprisal. ${ }^{90}$

One would expect such an all-embracing doctrine to have firmly entrenched roots in our labor law. The concept, however, is one of relatively recent coinage, specifically minted to meet a challenge to American business from an unexpected and particularly threatening quarter. The idea of supervisory loyalty and the legislation it inspired was a direct response to the specter of supervisory unionism, which loomed as

ss See supra notes 31-53 and accompanying text.

84 See supra notes 54-65 and accompanying text.

so See supra notes 73-82 and accompanying text.

86 Weinstock, Section 8(a)(1) Protection for Managerial, Confidential, and Supervisory Personnel, 33 LAB. L.J. 596, 597 (1982).

82 Hament, supra note 46 , at 281.

8s A. DEMARIA, supra note 11 , at 196. (1981).

${ }^{89}$ Lederer, Management's Right to Loyalty of Supervisors, 32 LAB. L.J. 83, 83

so See A. DeMaria, supra note 11, at 98; Hament, supra note 46, at 281. 
a "[m]eteor on the [i]ndustrial [r]elations [h]orizon" in post-World War II America. ${ }^{91}$

By the mid-1940's, the supervisor union movement, fueled by rising discontent among line managers, ${ }^{92}$ was already a rapidly growing and increasingly militant source of corporate concern. ${ }^{93}$ One commentator has written: "[W] hether [this movement] is measured by the volume or intensity of business comment about it, or the amount of energy employers dedicated to countering it, no single part of the rank-and-file challenge to management control was as important."94 Fearful that unionized supervisors-necessarily dependent upon the rank-and-file unions for support-might turn "mass production into just sheer mob production," management quickly turned to legal channels for relief from the onslaught of supervisory unionism. Relief, however, was not forthcoming. The NLRA ambiguously extended its protective ambit to cover all "employees," without mentioning whether supervisors were to be considered as such. ${ }^{98}$ The NLRB, bound to construe the NLRA,

91 Larrowe, A Meteor on the Industrial Relations Horizon: The Foreman's Association of America, 2 LAB. HIST. 259, 259 (1961). For other accounts of the supervisory union movement, see H.J. HARris, The Right to Manage: INDUSTRIAl ReLATIONS POLICIES OF AMERICAN BusINESS IN THE 1940's, at 74-87 (1982); G. Tomlins, The State and the Unions: Labor Relations, Law, and the ORGANIZED LABOR MOVEMENT IN AMERICA, 1880-1960, at 264-66 (1985).

${ }_{22}$ The rise of complex, bureaucratic industries and the onset of blue collar unions diminished the supervisors' degree of shop level control. Thus, one can see the growth of supervisors' unions as an attempt by the supervisors to protect their independence and responsibility. See H.J. HARRIS, supra note 91, at 75-78.

23 The Foreman's Association of America (FAA), founded in 1941, claimed nearly 50,000 members with more than 300 chapters in 20 states and Canada by 1947. See Larrowe, supra note 91 , at 260 . By 1946, the two largest independent supervisors' unions enjoyed a combined membership of almost 100,000; thousands more line managers were members of blue collar unions. See H.J. HARRIS, supra note 91, at 75. A survey conducted that year showed that while only $7 \%$ of supervisors were actually organized, $11 \%$ wished to be and $33 \%$ believed organization was necessary. See id. Supervisors' unions pressed for recognition by engaging in massive and distuptive strikes in key sectors of the wartime economy. In a major wave of supervisor strike activity during 1943-44, for example, the United States Bureau of Labor Statistics reported that approximately 20 work stoppages occurred in the shipbuilding, steel, aluminum, coal mining, and airplane production industries among others, involving 131,000 employees and resulting in a loss of 699,156 days of work. See Larrowe, supra note 91, at 281-82.

H.J. HARRIS, supra note 91, at 74-75.

${ }^{83}$ Statement of C.C. Carlton, Vice President, Motor Wheel Corp.; President, Automotive Manufacturer's Association, quoted in H.J. HARRIS, supra note 91, at 87.

Section 2(3) of the NLRA (Wagner) reads:

When used in this Act-

The term "employee" shall include any employee, and shall not be limited to the employees of a particular employer, unless the Act explicitly states otherwise, and shall include any individual whose work has ceased as a consequence of, or in connection with, any current labor dispute or because of any unfair labor practice, and who has not obtained any other 
vacillated wildly on the issue, first certifying bargaining units of supervisory employees, ${ }^{97}$ then reversing itself and denying supervisors the right to organize, ${ }^{98}$ then finally reverting to its original position, ${ }^{99}$ albeit with certain misgivings and a thinly veiled plea for legislative reform. ${ }^{100}$ When the matter finally reached the Supreme Court in Packard Motor Car Co. $v . N L R B,{ }^{101}$ the Court found "no basis in [the] Act whatever for holding that foremen are forbidden the protection of the Act." 102 Moreover, the Court stated that Congress, not the Court, should "create exceptions or qualifications at odds with [the] plain terms" of the NLRA. ${ }^{103}$

\section{B. The Taft-Hartley Supervisory Exclusion Amendment}

Management had, in fact, asked Congress for a supervisory exception to the Wagner Act long before Packard had begun winding its way through the courts. When the NLRB initially sanctioned supervisors' unions in 1942, ${ }^{104}$ the Foremen's Association of America demanded recognition at General Motors. ${ }^{108}$ The frightened president of General Motors, Charles E. Wilson, quickly beseeched congressional allies for aid. ${ }^{108}$ Representative Howard .W. Smith of Virginia responded, proposing a rider to amendments of the Selective Training and. Service $\mathrm{Act}^{107}$ that would forbid managers to bargain collec-

regular and substantially equivalent employment, but shall not include any individual employed as an agricultural laborer, or in the domestic service of any family or person at his home, or any individual employed by his parent or spouse....

Ch. $372, \S 2,49$ Stat. 449,450 (1935) (codified as amended at 29 U.S.C. § 152(3) (1982)).

97 See Godchaux Sugars, Inc., 44 N.L.R.B. 874 (1942); Union Collieries Coal Co., 41 N.L.R.B. 961 (1942)

88 See Maryland Drydock Co., 49 N.L.R.B. 733 (1943).

90 See Packard Motor Car Co., 61 N.L.R.B. 4 (1945).

100 See Jones \& Laughlin Steel Corp., 71 N.L.R.B. 1261, 1262-63 (1946) (quoting Jones \& Laughlin Steel Corp., 66 N.L.R.B. 386, 403 (1946)):

We can discover no authority to decide this case on the basis of personal opinion as to what might or might not be best for the respondent or the employees or even for the operation[s] of the Board itself. We are administrators, not legislators .... The Act as written today, requires that we protect the right of employees [including supervisory employees] to bargain collectively .... So long as the Congress of the United States imposes no limitation . . . it is not for us to do so.'

101330 U.S. 485 (1947).

102 Id. at 490.

103 Id.

104 See supra note 97.

108 See Larrowe, supra note 91, at 275.

108 See id. at 276.

107 Ch. 720, 54 Stat. 885 (1940). 
tively. ${ }^{108}$ Hearings on the proposed bill were held before the powerful House Military Affairs Committee. ${ }^{109}$ Before Congress could reach a decision, however, the NLRB reversed itself in Maryland Drydock Co., ${ }^{110}$ outlawing supervisors' associations and mooting the issue. ${ }^{111}$

By 1946, the NLRB once again favored supervisory unionism. ${ }^{112}$ Congress quickly reacquainted itself with the problem and reacted to the NLRB's position by introducing House Bill 4908, popularly named the Case Bill. ${ }^{113}$ Section 9 of the bill stripped supervisory employees of protection to unionize. ${ }^{114}$ Representative Smith, speaking in support of the provision, stated: "[S]upervisory employees . . . cannot serve both the employer and the union . . . . They may not sit on both sides of the bargaining table as members or officers of the union and, at the same time, as representatives of management."116 The Case Bill passed in both houses of Congress but was vetoed by President Truman. ${ }^{116}$ In his veto message, Truman criticized section 9, maintaining: "The full right of supervisory employees to the benefits of collective bargaining is one that cannot be lightly thrown aside."117

In the following year, however, Congress insisted on making sweeping changes in the Wagner Act, ${ }^{118}$ passing the changes over yet another presidential veto. ${ }^{110}$ Prominent among them were amendments to sections $2(3)$ and $2(11)^{120}$ of the Act and the enactment of section

108 H.R. 2239, 78th Cong., 1st Sess., 89 Cong. REC. 2206 (1943).

109 See Full Utilization of Manpower: Hearings Before the House Comm. on Military Affairs on H.R. 2239, H.R. 1742, H.R. 1728, and H.R. 992: Bills Relating to the Full Utilization of Manpower, 78th Cong., 1st Sess., (1943).

11049 N.L.R.B. 733 (1943).

111 See H.R. Rep. No. 245, 80th Cong., 1st Sess. 13 (1947), reprinted in 1 NLRB, Legislative History OF The Labor-Management Relations ACT, 1947, at 292, 304 (reprint 1985) [hereinafter LMRA HisTORY].

${ }_{112}$ See, e.g., Packard Motor Car Co., 61 N.L.R.B. 4 (1945).

113 Representative Norton originally introduced H.R. 4908. See 79th Cong., 2d Sess., 91 Cong. Rec. 11,523 (1945). The text of the Case Bill, H.R. 5262, 79th Cong., 2d Sess., 92 Cong. REc. 555 (1946) was subsequently substituted for the original text, in light of the importance of the subject. See 92 CoNG. REC. 661-62 (remarks of Rep. Clark). Hence, one generally refers to H.R. 4908 as the Case Bill.

114 See 92 Cong. Rec. 5927 (1946) (discussion of $\S 9$ by Rep. McCormack).

11892 ConG. REC. 668 (1946) (remarks of Rep. Smith).

116 See 1946 U.S. Code CoNG. SERv. 1686.

117 Id. at 1691.

118 Labor-Management Relations Act (LMRA) (Taft-Hartley), ch. 120, 61 Stat. 136 (1947) (codified as amended at 29 U.S.C. §§ 141-197 (1982)).

119 President Truman's veto message can be found at 93 Cong. Rec. 7485-88 (1947); the House override vote is set out in 93 CoNG. REC. 7489 (1947); and the Senate override vote is located at 93 CoNG. REc. 7538 (1947).

13029 U.S.C. $\S 152(3)$ provides in pertinent part: "The term 'employee' shall include any employee ... but shall not include . . . any individual employed as a supervisor . . . " 29 U.S.C. \& 152(11) provides:

The term 'supervisor' means any individual having authority, in the 
14(a) ${ }^{121}$ - the Taft-Hartley supervisory exclusion provisions.

In the Senate and House committee reports concerning these amendments, attention focused on the perceived dangers of unionized supervision. ${ }^{122}$ The House report, in a statement typifying such concerns, concluded: "There must be in management and loyal to it persons not subject to influence or control of unions . . . ."123 The exclusion amendments, continued the Senate report, were necessary "merely [to] relieve[] employers . . . from any compulsion . . . to accord to the front line of management the anomalous status of employees" for the purposes of collective bargaining. ${ }^{124}$

Thus, despite vague phrases sprinkled throughout the House re-

interest of the employer, to hire, transfer, suspend, lay off, recall, promote, discharge, assign, reward, or discipline other employees, or responsibly to direct them, or to adjust their grievances, or effectively to recommend such action, if in connection with the foregoing the exercise of such authority is not of a merely routine or clerical nature, but requires the use of independent judgment.

12129 U.S.C. § 164(a) (1982) provides:

Nothing herein shall prohibit any individual employed as a supervisor from becoming or remaining a member of a labor organization, but no employer subject to this subchapter shall be compelled to deem individuals defined herein as supervisors as employees for the purpose of any law, either national or local, relating to collective bargaining.

122 The House and Senate reports on Taft-Hartley both argued that supervisory unionism entailed a loss of productivity, breakdown of authority, and most importantly, an inevitable dominance of the supervisor's associations by rank-and-file unions. The House report included correspondence between Ford Motor Co. and the Foreman's Association of America, citing an instance in which a group of supervisors left work without permission to attend a union meeting, which hindered production and "involved grave risks to . . employees." H.R. ReP. No. 245, 80th Cong., 1st Sess. 15 (1947), reprinted in LMRA HISTORY, supra note 111, at 292, 305-06. Similarly, the Senate report noted:

The folly of permitting [certified supervisor's unions] is dramatically illustrated by what has happened in the captive mines of the Jones \& Laughlin Steel Corp. since supervisory employees were organized by the United Mine Workers under the protection of the act. Disciplinary slips issued by the underground supervisors in these mines have fallen off by two-thirds and the accident rate in each mine has doubled.

S. REP. No. 105, 80th Cong., 1st Sess. 4 (1947), reprinted in LMRA History, supra note 111 , at 407,410 . The House report also revealed evidence of a "closer and more intimate relation between the [Foreman's] [A]ssociation and the unions of men the foremen supervise than one ordinarily finds between unions affiliated together in the same federation, and a subservience of the association to unions of the rank and file that is rare among unions." H.R. REP. No. 245, 80th Cong., 1st Sess. 15 (1947), reprinted in LMRA HISTORY, supra note 111, at 292, 306. The Senate report echoed this finding. S. REP. No. 105, 80th Cong., 1st Sess. 4-5 (1947), reprinted in LMRA HISTORY, supra note 111 at $407,410-11$.

${ }^{123}$ H.R. REP. No. 245, 80th Cong., 1st Sess. 16 (1947), reprinted in LMRA History, supra note 111 , at $292,307$.

124 S. REP. No. 105, 80th Cong., 1st Sess. 5 (1947), reprinted in LMRA HrsTORY, supra note 111 , at $407,411$. 
port proclaiming the need for "supervisory loyalty,"125 it is clear from the committee prints that the impetus behind the legislation was to prohibit supervisors' unions from asserting their right to exist under the aegis of federal labor law. ${ }^{128}$ This was made even clearer in the congressional debates regarding the exclusionary provisions. Representative Claude Pepper, speaking in opposition, correctly complained that the effect of the amendments was "to deny to supervisory personnel . . . the right of making common cause against management in order to better their wages and working conditions." ${ }^{\text {127 }}$ A senator, arguing for the bill, reasoned that "where the supervisor has to represent management, it seems only proper that he should not be in the category of being union-minded . . . . That is all the supervisor provision takes care of "128

Congress's definition of the term "supervisory loyalty" thus was narrowly drawn when the Taft-Hartley Amendments were enacted. Congress intended the doctrine to embrace only those situations in which management had reason to fear that its agents were "being union-minded," i.e., were affirmatively aiding or actively associating with collective organizations. This limited conception of the purpose of the exclusionary provisions was accepted by the NLRB. On its first occasion to comment on the provisions, ${ }^{129}$ the NLRB stated:

[I]n considering [the supervisor exemptions] Congress was concerned only with the relative advisability of barring or continuing the statutory protection formerly accorded to supervisors who wished to join unions and bargain collectively. By its enactment, Congress did no more than effectuate its decision to remove any compulsion upon employers to bargain collectively with unions of supervisors or to respect the right of supervisors to organize. ${ }^{130}$

Similarly, when called upon to construe the Taft-Hartley supervisor

125 See H.R. ReP. No. 245, 80th Cong., 1st Sess. 14 (1947) ("[E]mployers . . . are entitled to loyal representatives in the plants."); $i d$. at 17 ("[N]o one, whether employer or employee, need have as his agent one who is obligated to those on the other side, or one whom, for any reason, he does not trust."), reprinted in LMRA HiSTORY, supra note 111 , at $292,305$.

128 Congress did not place an affirmative ban on supervisor's unions; it merely relieved the employer from the obligation to recognize and bargain with them under the dictates of the NLRA. See 29 U.S.C. \& 164(a) (1982); S. REP. No. 105, 80th Cong., 1st Sess. 5 (1947), reprinted in LMRA HisTORY, supra note 111, at 407, 411.

12793 CoNG. REC. 4360 (1947) (remarks of Rep. Pepper).

198 Id. at 4283 (remarks of Sen. Smith) (emphasis added).

199 Inter-City Advertising Co., 89 N.L.R.B. 1103 (1950), enforced as modified, 190 F.2d 420 (4th Cir. 1951), cert. denied, 342 U.S. 908 (1952).

${ }^{130}$ Id. at 1107. 
exceptions, the Supreme Court, on three different occasions, ${ }^{131}$ had little difficulty determining "that Congress'[s] dominant purpose in amending [sections] 2(3) and 2(11), and enacting [section] 14(a) was to redress a perceived imbalance in labor-management relationships that was found to arise from putting supervisors in the position of serving two masters with opposed interests."132

This understanding of congressional intent, initially endorsed by the NLRB and apparently adopted by the Court, has not prevailed in dominant labor law discourse. Ignoring or completely overlooking the industrial context in which these provisions were framed, commentators have stretched the meaning of the supervisor exemptions to evince evidence of a "congressional determination that an employer must be free to discharge and discipline supervisors in furtherance of its legitimate interest in opposing unionization by lawful means."133 In response to this overly expansive reading of the supervisory loyalty doctrine, the NLRB has fashioned an unprincipled standard that does not adequately protect either employees' organizational rights or workplace harmony.

\section{The Protected Status of Supervisors in Union Election Campaigns: An Unsatisfactory Standard}

The history of cases concerning the legality of a supervisor's discharge for refusing to aid her employer in fighting a union organization drive is long and problematic. Board decisions prior to the Taft-Hartley Amendments found supervisors protected in such situations not only to vindicate their "personal rights under the Wagner Act but also on the basis that the discharge coerced . . . nonsupervisory employees in the free exercise of their rights." ${ }^{\prime 34}$ The cases also failed to distinguish

131 Florida Power and Light Co. v. International Bhd. of Elect. Workers Local 641, 417 U.S. 790, 807-12 (1974); Beasley v. Food Fair of N.C., 416 U.S. 653, 659-62 (1974); NLRB v. Bell Aerospace Co., 416 U.S. 267, 301-02 (1974) (White, J., dissenting in part).

138 Beasley, 416 U.S. at 661-62.

133 Brod, The NLRB in Search of a Standard: When is the Discharge of a Supervisor in Connection with Employees' Union or Other Protected Activities an Unfair Labor Practice?, 14 IND. L. REv. 727, 729 (1981).

1s4 Hament, supra note 46, at 282. See, e.g., Vail Mfg. Co., 61 N.L.R.B. 181 (1945), enforced, 158 F.2d 664 (7th Cir.), cert. denied, 331 U.S. 835 (1947).

[T]he respondent discharged [supervisors] for refusing to assist it in the commission of an unfair labor practice and thereby violated section $8[(a)](3)$ of the Act .... Moreover, the discharge[s] . . interfere[d] with, restrain[ed], and coerce[d] the employees in the exercise of the rights guaranteed in Section 7 of the Act, and hence in addition constituted an independent violation of Section $8[(a)](1)$. 
between reprisals against supervisors for not participating in "lawful" anti-union campaigns versus reprisals for refusing to engage in unfair labor practices. In Richter's Bakery, ${ }^{135}$ for example, a supervisor, instructed by his superior merely to talk to the shop's employees to discourage union sentiment, refused, despite the offer of a raise if he were to "stick by" the employer in his attempt to quell the organizational fervor. ${ }^{136}$ The NLRB found that the supervisor's subsequent dismissal constituted a section $8(\mathrm{a})(3)$ violation $^{132}$ and ordered his reinstatement. The NLRB also held: "The discriminatory discharge of a supervisory employee because he refuses to aid his employer in restraining employees from joining a union itself discourages union membership among other employees, and thus falls within the prohibition of the Act."138

The legislative changes engendered by the Taft-Hartley Amendments prohibited supervisors from asserting their "personal" right to resist discriminatory discharges. The Amendments did nothing, however, to dilute the rights of supervisors' subordinate employees to engage freely in organizational activity. The NLRB addressed this issue in Inter-City Advertising Co. ${ }^{139}$ In this case, supervisor Peeler was discharged for failing to report to his employer the concerted activities of those in his charge. The NLRB, agreeing with the trial examiner, held that it was "reasonable to infer that the [employer's] reason for requiring such reports was to assist it in its campaign against the Union"140 and that "the discharge of supervisors for refusing to aid in such a campaign unlawfully interferes with, restrains, and coerces the nonsupervisory employees involved."141 Even though Peeler was no longer personally protected by the labor law, there was "nothing in the amended Act that change[d] the rights of nonsupervisory employees in ... situations such as this, where the discharge of a supervisor constitutes an invasion of the rights guaranted [sic] to nonsupervisory employees."142 The NLRB found Peeler's reinstatement with backpay "necessary in order to restore to the ... nonsupervisory employees their full freedom to exercise the rights guaranteed them in Section 7 of

Id. at $182-83$.

1ss 46 N.L.R.B. 447 (1942), enforced, 140 F.2d 870 (5th Cir.), cert. denied, 322

U.S. 754 (1944).

158 See id. at 478.

187 See supra note 62.

18846 N.L.R.B. at 450.

18089 N.L.R.B. 1103 (1950), enforced as modified, 190 F.2d 420 (4th Cir. 1951), cert. denied, 342 U.S. 908 (1952).

140 Id. at 1106.

141 Id.

${ }^{142}$ Id. at 1108. 
the Act."143

Unfortunately, post-1947 cases cut back on supervisory protection in one important respect. Supervisors were considered immune from reprisal only when they refused to engage in activities determined by the NLRB to be unfair labor practices. ${ }^{144}$ Thus, if an employer instructed her supervisor to engage in an activity that was found to be lawful anti-union campaigning, the reluctant supervisor was accorded no protection. ${ }^{145}$ In these cases, supervisors could be "brow beaten [sic], harassed, threatened, and discharged for failure to prevent the unionization of the establishment where they are employed, or . . . [for having] exerted insufficient energy in discovering information concerning the union and thereby fail[ing] to assist the employer's anti[-]union campaign."146

At first glance, this standard for supervisory protection in the context of a union representation drive appears simple, straightforward, and appealing. Given that the scope of the supervisor's protection is defined only as that which is necessary to protect the organizational rights of the rank-and-file, ${ }^{147}$ it seems logical to predicate supervisory immunity from reprisal upon a showing that such orders, if obeyed, would interfere with, restrain, or coerce subordinate employees. The superficial attraction of this approach, however, cannot mask the persistent practical problems it fosters. It creates a standard that is both incoherent and inconsistent, affording little practical guidance for supervisors and inadequate protection for their rank-and-file subordinates.

The NLRB has been chronically unable to delineate precisely what sorts of instructions to supervisors constitute demands to perform unfair labor practices. ${ }^{148}$ In Didde-Glaser, Inc., ${ }^{148}$ for example, two

$143 I d$.

144 See, e.g., Howard Johnson Motor Lodge, 261 N.L.R.B. 866 (1982), enforced, 702 F.2d 1 (1st Gir. 1983); Belcher Towing Co., 238 N.L.R.B. 446 (1978), enforced in part, enforcement denied in part, and remanded in part, 614 F.2d 88 (5th Cir. 1980); Newton Joseph, 225 N.L.R.B. 294 (1976); Dewey Bros., 187 N.L.R.B. 137 (1970), enforced sub nom. NLRB v. General Plastics Corp., 457 F.2d 511 (5th Cir. 1972); Miami Coca-Cola Bottling Co., 140 N.L.R.B. 1359 (1963), enforced in part, 341 F.2d 524 (5th Cir. 1965); Brookside Indus., 135 N.L.R.B. 16, enforced, 308 F.2d 224 (4th Cir. 1962); Talladega Cotton Factory, 106 N.L.R.B. 295 (1953), enforced, 213 F.2d 209 (5th Cir. 1954).

145 See, e.g., Didde-Glaser, Inc., 233 N.L.R.B. 765 (1977); Western Sample Book \& Printing Co., 209 N.L.R.B. 384 (1974); Southwest Shoe Exch. Co., 136 N.L.R.B. 247 (1962);

146209 N.L.R.B. at 390.

147 See 29 U.S.C. $\S 158(a)(1)$ (1982).

148 The Board's inability to set down guidelines has been widely noted. See, e.g., Hament, supra note 46, at 282; Weinstock, supra note 86, at 599-60; Note, The Supervisor as an American Hostage: Belcher Towing Co. v. NLRB, 41 LA. L. REv. 
supervisors were discharged for their inability to discuss adequately how the employees felt about the union. ${ }^{150}$ Similarly, in Dewey Brothers, ${ }^{151}$ a supervisor was dismissed for his refusal to talk to his subordinates to "find out how they felt about the Union."152 In the former case, the NLRB agreed with the administrative law judge (ALJ) and found no violation. It concluded that the employer had "demanded only that supervisors be deftly partisan, and constantly strive to assess voting inclinations among the rank-and-file."15s Even though such an assessment required that the supervisor identify employees by name and had "as an outgrowth specific plans to convert voters,"154 the NLRB held that the supervisors "were not in fact directed to commit unfair labor practices," and that therefore "both discharges were for good cause."155 In the latter case, the ALJ also initially found no violation in the reluctant supervisor's discharge. ${ }^{158}$ The NLRB remanded, however, noting specifically: "[T]he record contain[ed] testimony that [the supervisor] was given instructions to find out how the employees felt about the Union ..., which instructions [he] refused to carry out."157 The NLRB ordered the ALJ to determine whether the supervisor had been dismissed because of this refusal. The ALJ decided that the dismissal did stem from the supervisor's refusal, found the spurned instructions unlawful, and recommended reinstatement. ${ }^{168}$ The NLRB agreed. ${ }^{158}$

Additional instances of similar facts yielding divergent results in this area of NLRB jurisprudence have been noted by others. ${ }^{160}$ All con-

1328, 1334 (1981); Note, Limiting an Employer's Liability for Firing a Supervisor for Union Activity, 59 Notre DaMe L. Rev. 270, 280 (1983).

140233 N.L.R.B. at 765.

100 See id. at 767.

181187 N.L.R.B. 137 (1970), enforced sub nom. NLRB v. General Plastics Corp., 457 F.2d 511 (5th Cir. 1972).

${ }_{182} I d$. at 141 .

153233 N.L.R.B. at 769.

168 Id. at n.8.

165 Id. at 769 .

188 See 187 N.L.R.B. at 139.

187 Id. at 140 .

188 See id. at 142.

158 See id. at 137.

100 Weinstock, supra note 86, at 599-600, for example, compared Talladega Cotton Factory, 106 N.L.R.B. 295 (1953), enforced, 213 F.2d 211 (5th Gir. 1954), with Western Sample Book \& Printing Co., 209 N.L.R.B. 384 (1974). In both cases, the employer issued vague directives to supervisors. In the former, supervisors were instructed to "get out there and stop' the union." Weinstock, supra note 86, at 600 (quoting 106 N.L.R.B. at 310). In the latter, they were ordered to listen to workers and find out "what was going on about the union, and to try to discourage [the employees] from going union." Id. (quoting 209 N.L.R.B. at 386). Discharges for failure to comply with these requests followed in both cases. In Talladega, the dismissals were held to be "predicated upon the supervisors' failure to prevent unionization . . . by 
clude that the standard for determining, in a given fact situation, whether instructions to supervisors are lawful is unworkably unclear. Furthermore, the test for deciding the lawfulness of the supervisor's discharge is often fundamentally at odds with the desired aim of preserving supervisor loyalty. Line managers who have engaged in acts of "outright disloyalty"161 by divulging confidential management information to their subordinates or actively fomenting unionization in their shops, for example, have been held, in some cases, ${ }^{\mathbf{1 6 2}}$ to be protected from adverse employer reaction. By contrast, some supervisors who have expressed their neutrality or have even made good faith, albeit unsuccessful, attempts to comply with management's demands have found no redress for their consequent discharges. ${ }^{163}$

The incoherence and inconsistency of this standard means that the reluctant line supervisor, for all practical purposes, is left unprotected. It is surely an understatement to note:

[A] great deal of sophistication is required of a supervisor who does not wish to participate in interrogation, surveillance, or antiunion campaigning. If the activity requested by the employer does not constitute an unfair labor practice or a restraint on employees' Section 7 rights, the supervisor's discharge will not be protected under Section $8(a)(1)$ of the Act .....164

Indeed, few supervisors would profess confidence in their ability to comprehend the vagaries of this area of NLRB law. Their only alternative, then, short of brazenly risking reprisal, is to participate as en-

means of unfair labor practices at [the employer's] behest," and were found unlawful. Id. In Western Sample, by contrast, no violations were found. This was so despite the fact that the instructions received in both cases were nearly identical and, as Weinstock observed, "[t]he resulting restraint and coercion of statutory employees, which produces the Section 8(a)(1) protection for the supervisor, would appear to be present in both ...." Id.

161 See Lederer, supra note 89 , at 89.

162 In Buddies Super Markets, 223 N.L.R.B. 950 (1976), enforcement denied, 550 F.2d 39 (5th Cir. 1977), a supervisor who revealed to his pro-union subordinate that management was considering "building a case" for discharge against him was protected from dismissal. See id. at 950; Lederer, supra note 89, at 89-90. In Pioneer Drilling Co., 162 N.L.R.B. 918 (1967), enforced, 391 F.2d 961 (10th Cir. 1968), and DRW Corp., 248 N.L.R.B. 828 (1980), discharged supervisors who were admitted union adherents were ordered reinstated. The effect of these decisions, noted one commentator, "was to compel an employer to reinstate, with back pay" the "discharged supervisor . . . [who was] actively involved in a unionization drive among employees or in similar activities not in higher management's best interests." Brod, supra note 133, at 730 .

163 See, e.g., Didde-Glaser, Inc., 233 N.L.R.B. 765 (1977).

104 Weinstock, supra note 86 , at 601 . 
thusiastically as possible in management's anti-union campaign. ${ }^{165}$

The consequences of this "choice," as demonstrated above, ${ }^{186}$ can be devastating to employees' exercise of protected section 7 rights and to the proper functioning of the workplace. Clearly, in the context of a consultant-led campaign, replete with pressured demands and thinly veiled threats, a per se protective standard for the reluctant line supervisor is warranted to maintain the NLRA values of employee free choice and industrial peace. ${ }^{167}$ Providing such protection, moreover, would not require a radical departure from the principles of prior case law. The ingredients necessary for a viable, substantive standard of supervisory protection in representation election campaigns exist in the NLRB's own past precedent.

\section{The Cannon Electric Approach: A Principled Resolution}

The NLRB has developed several tests by which to determine whether an employer or her agent has committed a section 8(a)(1) violation during a union representation election campaign. One test focuses on whether the employer required line management to engage in unfair labor practices. The limitations of this standard with regard to a reluctant supervisor have already been shown. ${ }^{168} \mathrm{~A}$ closely related alternative approach, the Cannon Electric ${ }^{169}$ or "coercive tendency" test, holds more promise.

The NLRB initially proposed this approach in a decision rendered shortly after the enactment of the Taft-Hartley Amendments. In Dixie Shirt Co., ${ }^{170}$ a supervisor had been ordered to identify union organizers in the plant. Although the supervisor made no effort to comply with

xes See Lagerfeld, supra note 2 , at 9.

The Reagan NLRB has exacerbated the uncertainties of this area of the law in two recent decisions. While reaffirming that an employer violates $\S 8(a)(1)$ of the Act by discharging a supervisor for her refusal to commit an unfair labor practice, see Parker-Robb Chevrolet, 262 N.L.R.B. 402 (1982), enforced sub nom. Food \& Commercial Workers Local 1095 v. NLRB, 711 F.2d 383 (D.C. Cir. 1983), the NLRB has also held that even if an employer expressly instructs supervisors to commit unfair labor practices, such instructions will not constitute a $\S 8(\mathrm{a})(1)$ violation if they are neither carried out by supervisors nor disclosed to rank-and-file employees. See Resistance Technology, Inc., 280 N.L.R.B. No. 117, 122 L.R.R.M. (BNA) 1321 (June 24, 1986). The apparent practical import of these arguably inconsistent cases is that an employer or a consultant can demand that a supervisor engage in any counter-union activity, even if it is expressly prohibited by the NLRA, and compel obedience to such a demand up to the point of discharge.

${ }^{186}$ See supra text accompanying notes 54-82.

107 See supra note 24 and accompanying text.

168 See supra text accompanying notes 144-64.

168 151 N.L.R.B. 1465 (1965), overruled, Resistance Technology, Inc., 280 N.L.R.B. No. 117, 122 L.R.R.M. (BNA) 1321 (June 24, 1986).

17079 N.L.R.B. 127 (1948), enforced, 176 F.2d 969 (4th Cir. 1949). 
this directive, he was not discharged. The NLRB nonetheless found a section $8(a)(1)$ violation in the demand itself. It reasoned that because the information sought by management "could have been used . . . for no other purpose" than to interfere with employees' protected organizational rights, the fact that such information was never supplied "d[id] not excuse the violation."171 The NLRB announced that the test that should be used to determine whether the employer violated section $8(a)(1)$ was "whether the [employer] engaged in conduct reasonably calculated or tending to interfere with the free exercise of employee rights under the Act."172

The NLRB, by implication, rejected Dixie Shirt within one year ${ }^{173}$ but revived it with renewed vigor only three years later in H.N. Thayer Co. ${ }^{174}$ In that case, two supervisors were commanded to "keep [their] ears open" and report the identities and activities of union adherents. ${ }^{178}$ The NLRB determined that "such instructions [we]re unlawful whether or not they [we]re accompanied by a direction that supervisors use unlawful means to obtain the information, and whether or not the instructions [we]re ever carried out."176 Echoing Dixie Shirt, the NLRB maintained that the directives themselves were unlawful because, inter alia, "they constitute[d] an attempt to obtain the kind of information which can be used by the employer for no other purpose than to interfere with the employees' right to self-organization."177

In Cannon Electric, the NLRB embraced the theory that an employer's instructions are unlawful when they exhibit a tendency toward coercion or interference with protected section 7 rights. ${ }^{178}$ In this case, the employer instructed his line supervisors, through a series of memoranda, to evaluate the union sentiments of their subordinates and to identify employees with strong union sympathies. ${ }^{179}$ The supervisors complied with the orders, and the Board found a violation. The Board took administrative notice that it was "continually confronted with cases involving unlawful discrimination against employees where the

17179 N.L.R.B. at 128.

172 Id. (emphasis added).

173 In Empire Pencil Co., 86 N.L.R.B. 1187 (1949), enforced, 187 F.2d 334 (6th Cir. 1951), the NLRB, without mentioning Dixie Shirt, refused to find a $\$ 8(a)(1)$ violation when an employer's instruction that a supervisor supply him with the names of union adherents was never carried out.

17499 N.L.R.B. 1122 (1952), enforced, 213 F.2d 748 (1st Gir.), cert. denied, 348

U.S. 883 (1954).

17599 N.L.R.B. at 1125.

178 Id.

177 Id.

178151 N.L.R.B. at 1465.

179 See id. at 1466. 
prelude to the discrimination was the employer's attempt systematically to investigate the sympathies of his employees."180 The court held:

The frequency of a pattern of employer conduct associating discrimination against union adherents with employer's efforts to learn the names of union activists supports the conclusion that there is a "danger inherent" in such conduct: a tendency toward interference with the exercise by employees of their organizational rights. $\therefore$. Accordingly, we conclude that the tendency of Respondent's conduct justifies outlawing it. ${ }^{181}$

Although the "coercive tendency" cases do not involve supervisory discharge, they realistically recognize the great capacity of employers (or consultants) to chill employees' willingness to engage in collective activities. The cases affirm the importance of workers' organizational freedom and display the NLRB's displeasure regarding tactics designed to impinge upon it. The reasoning that underlies the tendency theory, particularly as enunciated in Cannon Electric and its progeny, ${ }^{\mathbf{1 8 2}}$ can

180 Id. at 1468 .

181 Id. at 1468-69 (footnote omitted).

182 Relying on Cannon Electric, the NLRB in Struksnes Construction Co., 165 N.L.R.B. 1062 (1967) said: "In our view, any attempt by an employer to ascertain employee views and sympathies regarding unionism generally tends to cause fear of reprisal in the mind of the employee if he replies in favor of unionism and, therefore, tends to impinge on his Section 7 rights." Id. at 1062.

This language was quoted with approval in Ray-Loc, Inc., 265 N.L.R.B. 1663, 1665 (1982). The Reagan NLRB, however, predictably first cut back and then foreclosed this approach. In A \& E Stores, 272 N.L.R.B. 737 (1984), the NLRB, without discussing these prior cases, announced: "An attempt to learn of employees' union sentiments . . . is not unlawful per se." Id. at 737. Member Zimmerman, dissenting in part, chastised the majority for completely ignoring the Cannon Electric rule. See $i d$. at 738.

In Resistance Technology, Inc., 280 N.L.R.B. No. 117, 122 L.R.R.M. (BNA) 1321 (June 24, 1986), the NLRB, in a 3-2 decision, overruled Cannon Electric to the extent that it held that an employer could be found to have violated the NLRA by instructing supervisors to commit unlawful acts, even if such orders were neither carried out nor disclosed to the employer's workers. See 280 N.L.R.B. No. 117, slip op. at 10, 122 L.R.R.M. at 1325. Members Babson and Stephens dissented and observed that the facts of the case made it unnecessary to consider the Cannon Electric rule (because the instructions to commit the unlawful acts had, indeed, been communicated to the employees), thus rendering the majority's reversal unprincipled. See id. at 13, 122 L.R.R.M. at 1325-26. Furthermore, the dissent pointedly remarked that the ruling was "inconsistent with established NLRB precedent concerning the surreptitious surveillance of union activities, and arguably inconsistent with those cases involving the discharge of supervisors for refusing to violate the Act." See id. at 14, 122 L.R.R.M. at 1326; see also supra note 165. As the dissent noted, the theory behind the NLRB's proscription of both surreptitious employer surveillance and supervisor discharge for refusal to commit unfair labor practices was that these actions constituted "the first step to discriminatory actions taken against employees" and that "Cannon Electric also focused on this need to deter violations of the Act." Id. Thus, as the dissent in Resistance 
be employed to fashion section $8(a)(1)$ protective measures for line supervisors reluctant to cooperate in management's anti-union campaign.

Under a Cannon Electric-type standard, the "tendency" of consultants' coercive tactics to harm employee free choice and industrial peace would "justiffy] outlawing [them]."183 Employers and consultants would be forbidden to force supervisors to carry out a counter-organizing plan. Any attempt to compel obedience to such a plan would constitute sufficient grounds for finding a section $8(\mathrm{a})(1)$ violation. ${ }^{184}$ Free from the demands of consultants, supervisors could either remain neutral during the election drive or voluntarily participate in management's campaign. In no case, however, could employers or consultants pressure supervisors to produce "no" votes or to engage against their will in conduct damaging to their subordinates' section 7 rights or overly disruptive of workplace harmony.

Furthermore, creating a per se rule out of the Cannon Electric doctrine would mitigate the problems of the current approach while preserving that element of supervisory loyalty that Congress originally intended to foster. The NLRB no longer would be forced to resort to the unworkable practice of according a supervisor redress from reprisal only if it determined, after the fact, that her refused duties, if performed, would have constituted an unfair labor practice. Thus, it would create a standard for supervisory protection that could be objectively and consistently applied, without forcing supervisors who may be unsure of their rights to engage in speculative conduct. Moreover, the standard would neither inhibit those supervisors who wish to participate in the management campaign nor would it embrace (as the present standard sometimes does) those supervisors who are either actively disloyal or affirmatively aiding the organizational effort. The congressional aim of releasing management from the burden of maintaining "union-minded" front-line supervision ${ }^{185}$ would be furthered, while the neutral-minded manager, her subordinates' organizational freedoms, and the efficient functioning of the workplace would be accorded a vital measure of protection.

Technology acknowledged, the "coercive tendency" theory behind the Cannon Electric approach is consistent with other areas of NLRB jurisprudence and is vital to protecting workers' statutory rights. It can, and should, be resurrected along the lines proposed in this Comment.

183151 N.L.R.B. at 1469.

184 See supra note 57.

185 See supra text accompanying notes 122-32. 


\section{Spotllghting the Union Busters: Reviving the}

LANDRUM-GRIFFIN ACT'S REPORTING REQUIREMENTS IN Consultant-Led, Supervisory-Run Management Gampaigns

Creating a viable protective mechanism for the reluctant line supervisor during a representation campaign would not affect that class of managers eager to follow the consultant's plan to thwart potential unionization. These managers present a formidable challenge to the organizing employee. ${ }^{188}$ Thus, as a method of halting management consultants' intrusions upon workers' section 7 rights, a proposal for supervisory protection alone is necessarily limited in its effectiveness. For this reason, a plan to restrict consultants' impermissible coercion of line supervisors must be coupled with comprehensive regulation of their permissible, non-coerced participation in the management campaign. Because the ability to operate surreptitiously encourages consultants to employ line managers to run their counter-organizing efforts, a proposal to force consultants to disclose publicly their activities promises to provide the keenest regulatory effect.

\section{A. The Consultant's Stake in Secrecy Versus the Benefit of Public Disclosure}

Management consultants summoned to orchestrate a counter-organizing campaign invariably insist upon at least one condition: that their presence in the plant remain unknown outside the upper echelons of management. Thus, to the rank-and-file worker, consultants are seen only as "out-of-state license plates parked in the executive parking lot." ${ }^{187}$ Although they remain the objects of the consultants' efforts, employees usually are totally unaware of the existence of such consultants. ${ }^{188}$

The consultants' ability to function behind the scenes is extremely advantageous to management for several reasons. The first involves the inestimable power of operating as an "anonymous Orwellian force" in the workplace, ${ }^{189}$ often leading workers to blame the disruptions and pressures associated with the representation campaign upon the only tangible "outside" force they can identify-the organizing union. ${ }^{180}$

180 See supra note 41 and accompanying text.

187 1 Pressures Hearings, supra note 2, at 636 (statement of William W. Winpinsinger, International President, International Association of Machinists).

${ }^{183}$ See id. at 35 (Kistler's statement); id. at 102 (Mills' statement).

1891 Pressures Hearings, supra note 2, at 35 (Kistler's statement).

190 See supra notes 74-75 and accompanying text. This ironic backlash against the organizing union is exacerbated by the power of the line supervisor to communicate the anti-union message to workers effectively. Consultant John A. Sheridan commented, 
Second, clandestine operations effectively mask some of the most damning aspects of the consulting industry: the enormous profits its practitioners garner for conducting anti-union campaigns and consultants' frequent interaction with public sector employers, a politically sensitive group.

Consultants generally choose to maintain secret salary arrangements during the campaign. Their hefty per diem fees, ${ }^{101}$ if brought to light and properly exploited by organizers, can prove fatal to the success of management's attempt to resist the union. ${ }^{192}$ Additionally, consultants regularly engage a number of public sector employers as clients. ${ }^{109}$ Once it is discovered that federal, state, and local monies are being utilized to finance union avoidance schemes, ${ }^{194}$ substantial adverse public reaction often results. ${ }^{188}$

"If you're an employee, and you're gonna vote on a union election next Tuesday, who are you more likely, and prone, to believe and listen to? Your immediate supervisor, who hands you your paycheck, or John Sheridan, who comes in like the deus ex machina?" BNA Report, supra note 2, at 40; see also 3 Pressures Hearings, supra note 2, at 187-88 (Muehlenkamp's statement).

${ }^{181}$ In 1980 , estimated per diem fees in the management consulting industry averaged from $\$ 500$ to $\$ 850$ per agent. See 1 Pressures Hearings, supra note 2 , at 33 (Kistler's statement). According to a 1983 article, one consultant regularly charges $\$ 225$ an hour for "educational meetings with groups of managers." English, supra note 2, at 64; see also Fulmer, supra note 2, at 21; fee figures cited supra note 8 .

182 See Paige, Breaking the Busters, Mother Jones, May 1980, at 52 ("Probably one of the most effective tactics of all was publishing the university's union-busting budget. . . . Next to [the consultant's] reported $\$ 16,000$ monthly fee, the average secretary's salary looked like pin money."); Persuader Reports Help Bring Election Victory, 47 RUB SHEET 2 (March 1985).

${ }^{193}$ It is not known what percentage of public employers turn to management consultants to resist unionization. According to one union official, consultant activity in the health care field, which is heavily supported by public funds, is "widespread." BNA Report, supra note 2, at 7. The 1980 House subcommittee investigating the pressures in the workplace expressed "concern . . . with both the legitimacy and the full disclosure" of government subsidization of management consultants. PRessures RePORT, supra note 2 , at 40.

${ }^{194}$ See 1 Pressures Hearings, supra note 2, at 487-88 (testimony of Thomas M. Kerr, Professor of Industrial Admin. \& Law, Carnegie-Mellon Univ.); 2 Pressures Hearings, supra note 2, at 175-87 (prepared statement of Jules Bernstein, AFL-CIO); id. at 265-66 (testimony of Anthony Carnevale, Director of Legislation for AFSCME); PRESSURES REPORT, supra note 2, at 41.

198 Residents of Kenosha, Wisconsin, for example, upon learning that the city hospital was using state funds to finance a consultant campaign, staged a boycott of the facility which reduced its patient count to only $30 \%$ of its normal capacity. See Labor Forces Wisconsin Hospital to Fire Modern Management, 27 RUB SHEET 6 (July 1981). Wisconsin and Massachusetts recently have enacted legislation restricting state payments to health care institutions employing labor consultants. See 2 Pressures Hearings, supra note 2, at 248; Reimbursement to Health Care Providers for Union Busting: The Government Makes it Tougher, 46 RUB SHEET 3 (Dec.-Jan. 1985); State Legislative Action on Union Busting Consultants, 33 RUB SHEET 6 (July 1982). In 1984, the Department of Health and Human Services announced new Medicare regulations that prohibited reimbursement of "[c]osts incurred for activities directly related 
In the majority of cases, however, consultants' fees and activities in union representation election campaigns remain largely hidden from the workers and from public scrutiny. In contrast, the organizing union's finances and political structure are open for display during the representation election campaign and often are employed by management consultants for propaganda purposes. ${ }^{196}$ Thus, it seems only fair that employees considering unionizing be fully cognizant of the monetary lengths to which management is willing to go to remain unionfree. ${ }^{187}$ Furthermore, in an era of concessionary collective bargaining and austerity in the public fisc, the notion that secret payments are being drawn from workers' salaries and taxpayers' dollars to combat unionism suggests a need for regulation that requires public disclosure of such arrangements.

\section{B. "The Forgotten Law": The Consultant Reporting Provisions of the Landrum-Griffin Act}

The means by which to compel disclosure of consultants' activities and financial arrangements during union representation election campaigns actually have been available for over a quarter century. The Labor-Management Reporting and Disclosure Act (LMRDA) (Landrum-Griffin) of $1959^{198}$ was the product of the famous McClellan Committee on Improper Activities in the Labor or Management Field. ${ }^{199}$ In 270 days of well-publicized hearings, the McClellan Committee, created primarily to investigate union racketeering, uncovered much evidence of management abuse that generally occurred through labor-management "middlemen"- the direct ancestors of present day management consultants. ${ }^{200}$ Among the committee's five initial recommendations presented to Congress in 1958 was "legislation to curb ac-

to influencing employees respecting unionization . . . whether such activities are performed directly by the provider or through . . . [a] consultant or outside attorney." Reimbursement of Health Care Providers for Union Busting: The Government Makes it Tougher, 46 RUB SHEET 2 (Dec.-Jan. 1985).

100 See, e.g., L. JACKSON \& R. LEWIS, supra note 7, at 18-21; 20 RUB SHEET 3 (Sept. 1980).

${ }_{107}$ See 1 Pressures Hearings, supra note 2, at 61-62 (Kistler's statement). This argument, in fact, was made by Congress as a rationale for the Labor-Management Reporting and Disclosure Act (LMRDA) (Landrum-Griffin) requirements for employer reporting. See infra text accompanying notes 204-08.

108 Pub. L. 86-257, 73 Stat. 519 (codified at 29 U.S.C. § 401 (1982)).

109 See Beaird, Reporting Requirements for Employers and Labor Relations Consultants in the Labor-Management Reporting and Disclosure Act of 1959, 53 GEO. L.J. 262, 269-80 (1965).

${ }_{200}$ See id. at $269-70$. According to Beaird, among the major abuses uncovered by the Committee was the practice of hiring consultants to "provide labor spies or to keep employees from organizing." Id. at 270 . 
tivities of middlemen in labor-management disputes."201

Congress responded by enacting the LMRDA. The Senate committee report on the Act echoed the McClellan Committee's concern over "management middlemen flitting about the country on behalf of employers to defeat attempts at labor organization."202 The committee noted that these middlemen, in their efforts to combat unionism, engaged in activities "disruptive of harmonious labor relations."203 Furthermore, they accepted from employers "large sums of money" to develop and manage "organized campaigns ... for the purpose of interfering with the right of employees to join or not to join a labor organization of their choice." 204 The report concluded that such activities "should be exposed to public view, for if the public has an interest in preserving the rights of employees then it has a concommitant [sic] obligation to insure the free exercise of them." LMRDA's disclosure provisions for unions, the committee further reasoned: "[I]f unions are required to report all their expenditures, including expenses in organizing campaigns, reports should be required from employers who . . . engage such persons to carry on[] various types of activity, often surreptitious, designed to interfere with the free choice of bargaining representatives by employees." 206 The clear aim of such reports, continued the Senate report, would be to expose the deceptive practices of labor middlemen, that while not necessarily constituting illegal or unfair labor practices, were "not conducive to sound and harmonious labor relations" and tended to "interfere with the free choice of bargaining representatives."207 Once disclosed, Congress hoped that the pressure of public scrutiny would eliminate the most abusive of these practices. ${ }^{208}$

In its final form, then, title II of the LMRDA contains an extensive reporting and disclosure system ${ }^{20 \theta}$ for "labor relations consultants"

${ }^{201}$ S. REP. No. 1417, 85th Gong., 2d Sess. 450 (1958), quoted in Beaird, supra note 199 , at 270 .

${ }^{202}$ S. REP. No. 187, 86th Cong., 1st Sess. 10, reprinted in 1 NLRB, LEGISLATIVE History of THE LABOR-Management Reporting and Disclosure AcT of 1959 , at 406 (1959) [hereinafter NLRB].

${ }^{208}$ Id. at 12,1 NLRB at 408.

206 Id. at 10,1 NLRB at 406.

205 Id. at 11,1 NLRB at 407.

${ }_{208}$ Id. at $39-40,1 \mathrm{NLRB}$ at $435-36$.

${ }_{207} I d$. at $11,39-40,1 \mathrm{NLRB}$ at $407,435-36$.

${ }^{208}$ See Loomis, Employer and Consultant Reporting Requirements, in SYMPOSIUM ON THE LMRDA 391 (R. Slovenko ed. 1961).

${ }^{200} 29$ U.S.C. $\S 433$ (b) (1982) provides in pertinent part:

Every person who pursuant to any agreement or arrangement with an employer undertakes activities where an object thereof is, directly or indirectly- 
and employers. ${ }^{210}$ Upon undertaking any "agreement or arrangement ... directly or indirectly . . to persuade employees" with regard to their organizational rights, ${ }^{211}$ the consultant is required to submit two reports to the Secretary of Labor. The first, an "Agreement and Activities Report,"212 must be filed within thirty days of the commencement of the arrangement, and must contain a "detailed statement of [its] terms and conditions."213 The second, a comprehensive "Receipts and Disbursements Report,"214 is required to be filed annually for each year that the consultant is engaged in dissuading employees from unionizing.

In a symposium held shortly after the passage of the LMRDA, one student of labor law reiterated the purpose of these reporting

(1) to persuade employees to exercise or not to exercise, or persuade employees as to the manner of exercising, the right to organize and bargain collectively through representatives of their own choosing . . . shall file within thirty days after entering into such agreement or arrangement a report with the Secretary . . . containing the name under which such person is engaged in doing business and the address of its principal office, and a detailed statement of the terms and conditions of such agreement or arrangement. Every such person shall file annually, with respect to each fiscal year during which payments were made as a result of such an agreement or arrangement, a report with the Secretary ... containing a statement (A) of its receipts of any kind from employers on account of labor relations advice or services, designating the sources thereof, and (B) of its disbursements of any kind, in connection with such services and the purposes thereof.

210 The LMRDA's comparable reporting provisions for employers require, inter alia, a report for "any agreement or arrangement with a labor relations consultant . . . pursuant to which such person undertakes activities where an object thereof, directly or indirectly, is to persuade employees to exercise or not to exercise . . . the right to organize and bargain collectively through representatives of their own choosing." LMRDA § 203(a)(4), 29 U.S.C. § 433(a)(4) (1982).

21129 U.S.C. $\S 433$ (b) (1982).

212 Form LM-20, LMRDA REPORT, supra note 2, at 27.

21829 U.S.C. $\S 433$ (b) (1982).

214 Form LM-21, LMRDA REPORT, supra note 2, at 3. The circuits currently are split over the parameters of the LM-21 requirement, but the bulk of the case law reveals a high regard for broad disclosure of consultant activity. Thus, Humphreys, Hutcheson \& Moseley v. Donovan, 755 F.2d 1211, 1216 (6th Cir. 1985); Master Printers Ass'n v. Donovan, 699 F.2d 370, 371 (7th Cir. 1983), cert. denied, 464 U.S. 1040 (1984); Price v. Wirtz, 412 F.2d 647, 650 (5th Cir. 1969) (en banc); Douglas v. Wirtz, 353 F.2d 30, 32 (4th Gir. 1965), cert. denied, 383 U.S. 909 (1966), have all held that once a consultant engages in persuader activity, the reporting requirements are triggered for all services that the consultant performed for all of its labor relations clients during the fiscal year, including "advice" services that otherwise would not be reportable. Recently, however, the Eighth Circuit, in Donovan v. Rose Law Firm, 119 L.R.R.M. 3345 (1985), held that a consultant's persuader activity only compels her to reveal the services she performed for that particular client. This split may finally provoke some long-needed high court guidance on the LMRDA reporting requirements. 
requirements:

Congress apparently believed that many of these [consultant] activities, even if legal, are ethically or morally questionable and therefore proper subjects for exposure to the glare of public opinion. The theory with respect to these legal but perhaps ethically questionable practices is that a requirement to report them will result in their deterrence or elimination. ${ }^{215}$

If fully complied with, this regulatory scheme would curb consultants' noncoercive use of front-line supervision during a representation election campaign and arguably eliminate it entirely to the extent that it impinged upon employees' section 7 rights or industrial peace. Unfortunately, in "rel[ying] upon a system of reporting and disclosure to apply ... . corrective curbs"216 to consultants' practices, Congress underestimated consultants' considerable skills of legal evasion. Ironically, by operating primarily through front-line supervisors, consultants have successfully eluded, for two and a half decades, the reporting requirements specifically designed to regulate such campaign conduct. Thus, these provisions of the LMRDA have been a monument to noncompliance $^{217}$ and nonenforcement. ${ }^{218}$ Recently reporting on the state of the

215 Loomis, supra note 208, at 391 (citations omitted).

216 S. REP. No. 187, 86th Cong., 1st Sess. 11, 1 NLRB at 407.

212 From its inception, the LMRDA has inspired only a handful of labor relations consultants to file the requisite forms each year. See Bernstein, Union Busting, supra note 2, at 33-36, 78; Dopplet, When Does Representing Management Become Union Busting?, Student LAw., May 1980, at 30, 34. This is not to suggest that consultants do not engage in reportable activity. A 1978 survey of management attorneys showed that $64.6 \%$ had performed services that required LMRDA reports-but only $1.8 \%$ actually had filed for such activity. See Craver, The Application of LMRDA "Labor Consultant" Reporting Requirements to Management Attorneys: Benign Neglect Personified, 73 Nw. U.L. REv. 605, 625 (1978). A 1983 study of California management consultants showed an even more shocking rate of noncompliance. There, the authors estimated that $99 \%$ of all reportable activity over the past seven years had gone undisclosed. See Lawrence \& Williams, Union Busters and the Law: Consultant and Employer Non-Compliance with Reporting Requirements of the Landrum-Griffin Act in California, reprinted in Oversight Hearings, supra note 2, at 323.

${ }_{218}$ Despite the Department of Labor's congressional mandate to enforce the reporting provisions of the LMRDA, see LMRDA $\S 210,29$ U.S.C. $\S 440$ (1982), its chronic nonenforcement has been noted by academics such as Bernstein, Union Busting, supra note 2, at 32-34; Lawrence \& Williams, supra note 217, at 329; and by Congress, LMRDA REPORT, supra note 2, at 4-18; PREssuRes REPORT, supra note 2, at 45-47. Enforcement of the labor consultant provisions appears to have reached its lowest point during the current administration. See LMRDA REPORT, supra note 2, at 4 ("The Department of Labor's reduced enforcement of the Act's . . . consultant reporting and disclosure requirements since 1980 is so substantial that it approaches abandonment of its enforcement obligation."). The fact remains, however, that "[n]onenforcement of the Act has spanned six administrations of both political parties." PREs- 
LMRDA consultant disclosure provisions, the House Subcommittee on Labor-Management Relations aptly entitled its findings "The Forgotten Law."219

\section{Applying the LMRDA to Consultant-Led, Supervisory-Run Management Campaigns}

Management consultants freely admit noncompliance with the LMRDA reporting requirements. ${ }^{20}$ As the chairperson of the largest American consulting firm explained to a congressional subcommittee, because the firm's activities are "confined to consulting [with] and advising ... management and managerial personnel exclusively," it "does not . . . deal directly with employees" and thus "is not required to report."221 Two distinct theories, premised upon the LMRDA's statutory language and administrative interpretation, form the basis of consultants' belief that the Act does not apply to their activities. First, consultants maintain that their primary function during a representation election campaign-instructing and directing line supervisors to carry out their counter-organizing strategies-is exempt from disclosure by the language of the LMRDA itself. Section 203(c) excludes giving advice and agreements to give such advice ${ }^{222}$ from the reporting and disclosure provisions. Consultants contend that giving instructions to a supervisor merely constitutes providing advice to "the only people in management who have day to day contact with . . . the employees."223

Second, under a 1962 Department of Labor interpretation of the LMRDA, only direct contact with employees must be reported. ${ }^{224}$ Even if a supervisor-run, anti-union campaign could be construed as an

SURES REPORT, supra note 2 , at 47.

210 LMRDA REPORT, supra note 2.

230 See 3 Pressures Hearings, supra note 2, at 78 (Melnick's statement); Rodgers, Business is Booming for this Hardball "Union Buster," Boston Globe, Jan. 25, 1983, at 37 .

2313 Pressures Hearings, supra note 2, at 78 (Melnick's statement).

22229 U.S.C. $\S 433$ (c) (1982) provides:

Nothing in this section shall be construed to require any employer or other person to file a report covering the services of such person by reason of his giving or agreeing to give advice to such employer or representing or agreeing to represent such employer before any court, administrative agency, or tribunal of arbitration or engaging or agreeing to engage in collective bargaining on behalf of such employer with respect to wages, hours, or other terms or conditions of employment or the negotiation of an agreement or any question arising thereunder.

2333 Pressures Hearing, supra note 2, at 76 (Melnick's statement).

224 See Letter from Charles Donahue, Solicitor of Labor, to John L. Holcombe, Commissioner, Bureau of Labor-Management Reports (Feb. 19, 1962), reprinted and discussed in Bernstein, Union Busting, supra note 2, at 24-25. 
activity to which the reporting requirements of the LMRDA would apply, consultants claim that by interposing the line supervisor between the rank-and-file worker and themselves, they avoid "speak[ing] directly to employees."22s Thus, they contend that both the language and official construction of the Act excuses their noncompliance.

Neither argument can withstand close analysis. While some commentators agree that the LMRDA advice exemption generally permits consultants to "inform supervisors of the means they may legally utilize to encourage employees not to support a campaigning labor organization," ${ }^{228}$ this view is completely dependent upon the overly expansive conception of supervisory loyalty. ${ }^{227}$ Such a view maintains that one of the fundamental duties of a loyal line supervisor is to discourage unionism among her subordinate employees. As discussed above, the legislative history of the Taft-Hartley supervisory amendments reveals that Congress never espoused this view. ${ }^{228}$ Moreover, the section 203(c) advice exception simply is not applicable to the consultant-supervisor relationship. In an analogous situation, "[a] reasonable construction of 'advice' would hold it applicable to all activities of the lawyer in which it is contemplated that the client will be the ultimate implementing actor and in which the client retains the power to accept or reject the activities of the lawyer." ${ }^{229}$ Although the line supervisor is to be the "ultimate implementing actor" in the anti-union campaign, she hardly possesses the unqualified "power to accept or reject" the consultant's tactics. ${ }^{230}$ Furthermore, recently it has been persuasively argued that the "intensive sessions in which supervisors report back to the consultant on the day to day progress of a management campaign ... fall clearly under the ... reporting requirements."2s1

Consultants' reliance on avoiding direct contact with employees in order to be excused from filing under the LMRDA is even more misplaced. The plain language of section 203(b) of the LMRDA requires disclosure of any "activities where an object thereof is, directly or indirectly ... . to persuade employees."2s2 Indeed, such a strained understanding clashes with the clear purpose of the consultant provisions,

228 BNA Report, supra note 2, at 31.

${ }^{228}$ Craver, supra note 217, at 623; see also Lawrence \& Williams, supra note 217 , at 316.

227 See supra text accompanying notes 86-90.

298 See supra text accompanying notes 113-32.

229 Bernstein \& Sullivan, Lawyer Reporting and the Attorney-Client Privilege, in SYMPosium ON THE LMRDA, supra note 208 , at 414 (emphasis added).

230 See supra text accompanying notes 21-23 \& 38-53.

231 Lawrence \& Williams, supra note 217 , at 318.

23229 U.S.C. $\S 433$ (b) (1982) (emphasis added). 
which is exposing "to public view" the clandestine activities of management "middlemen."233 Moreover, the Department of Labor, upon whose narrow 1962 interpretation of the scope of LMRDA "persuasion" most consultants depend, has not limited itself to that standard in subsequent policy guidelines and civil actions. The Department's interpretive manual governing the consultant reporting provisions, for instance, maintains that the LMRDA "does not limit reports to situations where a consultant speaks directly to employees, but reporting depends rather on whether the activity in question has as an object to persuade employees."234 Furthermore, in its 1964 public guidelines regarding LMRDA reporting, the Department directed employers to file whenever they arrange for a consultant "to handle all phases of labormanagement relations . : . if the arrangements include activities that, directly or indirectly, are for the purpose of persuading employees about exercising their rights to organize and bargain collectively."2ss

Such unambiguous language certainly suggests that the Department of Labor is willing to require consultant compliance with the LMRDA reporting requirements in situations where front-line supervisors are used to pursue anti-union activity. In fact, on two occasions $^{236}$ it has instituted suit against consultants for failing to report their training and direction of supervisors during a union campaign. In 1975, the Secretary of Labor brought an action against the consulting firm of John Sheridan Associates for failing to report its activities during an Electrical Workers representation drive at a GTE telecommunications plant. ${ }^{297}$ In the course of its counter-organizing campaign, Sheridan advised supervisors of their legal rights and directed them to determine the union sentiments of those in their charge. ${ }^{238}$ Despite the consultant's complete absence of contact with GTE's nonsupervisory

2ss S. REP. No. 187, 1 NLRB, at 407.

234 OfFICE OF LABOR-MANAGEMENT STANDARDS AND ENFORCEMENT, UNITED STATES DePartment OF LABOR, INTERPRETIVE MANUAL $\S 263.200$, reprinted in LMRDA REPORT, supra note 2, at 30 attachment 5.

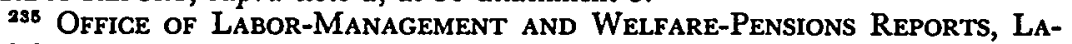
bor-Management Services Administration, United States Department of Labor, Technical Assistance Aid No. 6, Employer and Consultant ReportING 8 (1964), cited in Bernstein, Union-Busting, supra note 2, at 25-26.

${ }_{236}$ See, e.g., Marshall v. South Hills Health System, No. 81-66 (W.D. Pa. filed Dec. 28, 1981) (Secretary of Labor sued employer to compel disclosure of use of consultant to train supervisors and indirectly conduct an anti-union campaign.), cited in Brief for Plaintiffs-Appellants at 10-11 n.6, UAW v. Donovan, No. 84-5051 (D.C. Cir. filed Feb. 22, 1985); Dunlop v. John Sheridan Assocs., No. 75-C-4205 (N.D. Ill. filed Dec. 10, 1975) (Secretary of Labor successfully sued to compel consultant reports on "indirect" activity.).

${ }_{237}$ Dunlop v. John Sheridan Assocs., No. 75-G-4205 (N.D. Ill. filed Dec. 10, 1975); see GTE Lenkurt, Inc., 204 N.L.R.B. 921 (1973).

2ss See GTE Lenkurt, 204 N.L.R.B. at 926. 
workers, Sheridan, under court order, was directed to file "adequate and complete" LMRDA reports. ${ }^{239}$ A similar action in 1981 against the South Hills Health System netted comparable results. ${ }^{240}$

The combination of a proper understanding of the role of frontline supervisors in a representation campaign, the clear statutory language and legislative intent of the LMRDA, and the Labor Department's administrative policy and enforcement practice under the LMRDA compels the conclusion that the LMRDA reporting and disclosure provisions are fully applicable to all phases of a consultant-led, supervisor-run, anti-union drive. The deceptive practices of management consultants may be properly regulated under the LMRDA, halting the abuses that threaten employee free choice and industrial peace. As Justice Brandeis once remarked, "[p]ublicity is justly commended as a remedy for social and industrial diseases. Sunlight is said to be the best of disinfectants; electric light the most efficient policeman." ${ }^{241} \mathrm{Ex}$ posing consultants to the glare of the public spotlight will do more than patch "a gaping hole in the LMRDA's effectiveness;"242 it also will combat a pervasive industrial disease that currently weakens the statutory protections of American workers.

\section{CoNCLUSION}

Management consultants' use of front-line supervisors to conduct anti-union campaigns during union representation election drives is severely disruptive of employees' statutory organizational rights and the harmony of the workplace. Hostage to a pervasive view that a fundamental duty of line management is to aid employer resistance to unionism, supervisors are cajoled and coerced by consultants into believing that their livelihood depends upon the vigor they bring to the task of persuading their subordinates to forego unionization. The harassment suffered by supervisors usually translates into anger and frustration, which is ultimately directed against the rank-and-file workers, causing interference with their section 7 rights and eroding the efficient func-

2s9 See Oversight Hearings, supra note 2, at 767-68 (describing final order in Dunlop v. John Sheridan Assocs., No. 75-C-4205 (N.D. Ill. filed Dec. 10, 1975)).

${ }^{240}$ See Marshall v. South Hills Health System, No. 81-66 (W.D. Pa. Dec. 28, 1981), cited in Report Prepared for Bill Clay, Chairman, Labor-Management Relations Subcommittee, by the Majority Staff of the Subcommittee Concerning Enforcement of Consultant \& Employer Reporting Provisions of the Landrum-Griffin Act, reprinted in Oversight Hearings, supra note 2, at 18.

${ }_{241}$ Donovan v. Master Printers Ass'n, 532 F. Supp. 1140, 1149 (N.D. Ill. 1981) (quoting Buckley v. Valeo, 424 U.S. 1, 67 (1976) (per curiam) (quoting L. BRANDEIS, Other People's Money 62 (National Home Library Foundation ed. 1933))).

${ }^{242}$ Bernstein, Union Busting, supra note 2, at 28. 
tioning of the shop.

Furthermore, by employing line supervisors as the exclusive agents of the management campaign, consultants ensure that their presence, activities, and fee arrangements with the employer remain undisclosed. By maintaining a shadowy existence at the worksite, consultants enjoy a psychological advantage over the organizing union and frustrate public attempts to check the excesses of a proliferating industry. Consultants' use of supervisory personnel, therefore, demands both restriction and regulation.

The expansive doctrine of supervisory loyalty-the ideological underpinning that excuses consultant coercion of supervisors-has no statutory basis. In enacting the Taft-Hartley supervisory exclusion amendments, Congress was concerned only with the problem of supervisory unionism and intended merely to free management from having to contend with individuals serving two masters. Interpreters of these provisions, however, have misread congressional intent and consequently have created a body of incoherent and inconsistent common law that offers scanty legal guidance to supervisors and inadequate protection for workers. To shield the reluctant supervisor, a new standard must be developed from a revival of the NLRB's "coercive tendency" cases, which would render unlawful any attempt by employers or consultants to compel an unwilling line supervisor to participate in any phase of the management campaign.

To reach those situations where line managers are willing to comply with the consultant's instructions, the emphasis must shift from the rights of supervisory personnel to the duties of management consultants under the dormant reporting and disclosure provisions of the LandrumGriffin Act. Acknowledgement of the inequality inherent in the consultant-supervisor relationship-and a careful review of the language, legislative history, and administrative practice of the LMRDA - compels the conclusion that consultants should not evade scrutiny merely by using line supervisors to run their anti-union campaigns. Rather, the complete and faithful application of the LandrumGriffin reporting requirements to consultant-led, supervisor-run campaigns should police the activities of management consultants and preserve the statutory protections of the American laborer. 
. 